\title{
Civil Rights, World War II, and U.S. Public Opinion
}

\section{Steven White, Lafayette College}

\begin{abstract}
Scholars of American politics often assume World War II liberalized white racial attitudes. This conjecture is generally premised on the existence of an ideological tension between a war against Nazism and the maintenance of white supremacy at home, particularly the Southern system of Jim Crow. A possible relationship between the war and civil rights was also suggested by a range of contemporaneous voices, including academics like Gunnar Myrdal and activists like Walter White and A. Philip Randolph. However, while intuitively plausible, this relationship is generally not well verified empirically. A common flaw is the lack of attention to public opinion polls from the 1940s. Using the best available survey evidence, I argue the war's impact on white racial attitudes is more limited than is often claimed. First, I demonstrate that for whites in the mass public, while there is some evidence of liberalization on issues of racial prejudice, this generally does not extend to policies addressing racial inequities. White opposition to federal anti-lynching legislation actually seems to have increased during the war. Second, there is some evidence of racial moderation among white veterans, relative to their counterparts who did not serve. White veterans were more supportive of anti-lynching legislation in the immediate postwar period, and they offered stronger support for black voting rights in the early 1960s. However, they were not distinguishable on many other issues, including measures of racial prejudice and attitudes toward segregation.
\end{abstract}

Notions that World War II-particularly the logic of fighting a war against Nazi racism-led to increases in white support for black civil rights are widespread. Civil rights activists, journalists, academics, and others at the time regularly claimed that when shown "the gross discrepancy between our ideals and our practices," as one contemporaneous observer described it, white Americans would be forced to confront their own racial prejudices and legacies of discrimination, resulting in a major step forward for racial progress. ${ }^{1}$ Indeed, claims about World War II's impact on white racial attitudes can be found in sources ranging from contemporaneous accounts ${ }^{2}$ to present-day historical

Thanks to Ira Katznelson, Robert Shapiro, Robert Lieberman, the editors of $S A P D$, and the anonymous reviewers for helpful feedback. This project has also benefited from many comments and suggestions by participants at the Columbia University American Politics workshop, the Columbia-Princeton-Yale graduate student historical working group, the annual meetings of the Midwest Political Science Association and American Political Science Association, the University of Tampere's Institutions in Context workshop, and the Penn Program on Democracy, Citizenship and Constitutionalism graduate workshop.

1. Margaret C. McCulloch, "What Should the American Negro Reasonably Expect as the Outcome of a Real Peace?," Journal of Negro Education 12, no. 3 (1943): 565.

2. Gunnar Myrdal, An American Dilemma: The Negro Problem and Modern Democracy (New York: Harper \& Brothers, 1944); Charles Wallace Collins, Whither Solid South? A Study in Politics and Race Relations (New Orleans: Pelican, 1947); Howard W. Odum, "Social Change in the South," Journal of Politics 10, no. 2 (1948): 242-58. institutionalist scholarship $^{3}$ and scattered other sources like constitutional law books. ${ }^{4}$ Sometimes the claim is direct and central (e.g., Gunnar Myrdal's An American Dilemma); at other times, it is taken for granted in the background (e.g., Philip Klinkner and Rogers Smith's The Unsteady March). However, in making varied assumptions about the war's impact on white attitudes, such accounts have generally not analyzed public opinion surveys from the 1940s that might allow for a better empirical assessment of such claims.

This article provides such an assessment. Based on an analysis of the available survey evidence, I argue that the war's impact on white racial attitudes is more limited than is widely assumed. ${ }^{5}$ While there is some evidence white racial prejudice decreased during the war, this is generally not true for attitudes

3. Philip A. Klinkner and Rogers M. Smith, The Unsteady March: The Rise and Decline of Racial Equality in America (Chicago: University of Chicago Press, 1999); Daniel Kryder, Divided Arsenal: Race and the American State during World War II (New York: Cambridge University Press, 2000); Robert P. Saldin, War, the American State, and Politics since 1898 (New York: Cambridge University Press, 2010).

4. Alfred H. Kelly, "The School Desegregation Case," in Quarrels That Have Shaped the Constitution (rev. ed.), ed. John A. Garraty (New York: Harper \& Row, 1987).

5. Of course, "the war" itself did not directly impact civil rights politics. Rather, various actors used the opportunities presented by wartime to make new rhetorical claims and policy demands in the context of war. For a general discussion of the nature of "wartime," see Mary L. Dudziak, War Time: An Idea, Its History, Its Consequences (New York: Oxford University Press, 2013). 
toward racially egalitarian policies. White opposition to federal anti-lynching legislation seems to have actually increased during the war. I also assess whether serving in the war liberalized white veterans, relative to their nonveteran counterparts. I found a much more complex story among veterans. They are not distinguishable on a wide range of racial prejudice measures. However, they are distinctive on two issues: In the late 1940s, they were more likely to support federal anti-lynching legislation; and in the early 1960 s, white veterans in the South offered stronger support for black voting rights.

These results have implications for political science in several ways. First, this article serves as a useful corrective to common assumptions about the war's effects on white racial attitudes. The few political science analyses of how the war did impact civil rights have focused entirely on social movements and elite institutions. As such, their background claims about mass attitudes have not been fully substantiated. ${ }^{6}$ Second, this article complements work assessing the individual-level impacts of military service on black Southerners. ${ }^{7}$ While civil rights historians have long believed service in the Second World War had transformative impacts on black veterans-and this has been affirmed with survey analysis by Christopher Parker-there has been much less historical scholarship about white veterans in this regard, and none that I am aware of has utilized survey data. By combining analyses of surveys that identified veteran status in the war's immediate aftermath with the white sample of the 1961 Negro Political Participation Study survey that Parker used to analyze black veterans, this article complements previous scholarship by offering a different vantage point. Along with these specific contributions, this article also makes a more general contribution to the literature on attitudinal change, particularly the question of whether attitudes generally, and white racial attitudes in particular, are event-driven or stem largely from less contingent, more structural sources. ${ }^{8}$

The article proceeds as follows: I begin with historical background, particularly by situating the analysis

6. Klinkner and Smith, The Unsteady March; Kryder, Divided Arsenal; Saldin, War, the American State, and Politics.

7. Christopher S. Parker, Fighting for Democracy: Black Veterans and the Struggle against White Supremacy in the Postwar South (Princeton, NJ: Princeton University Press, 2009); Christopher S. Parker, "When Politics Becomes Protest: Black Veterans and Political Activism in the Postwar South," Journal of Politics 71 (2009): 113-31.

8. For example, Adam Berinsky argues wartime attitudes largely reflect peacetime patterns, suggesting an event like World War II should not necessarily drive white racial attitudes; see Adam J. Berinksy, In Time of War: Understanding American Public Opinion from World War II to Iraq (Chicago: University of Chicago Press, 2009). Paul Kellstedt's analysis of white racial attitude change in the 1950s and 1960s similarly suggests change is slower and more structural; see Paul Kellstedt, The Mass Media and the Dynamics of American Racial Attitudes (New York: Cambridge University Press, 2003). with reference to contemporaneous discussions of the war and civil rights in the 1940s. I then relate this to present-day academic accounts that have addressed these themes and show what is missing from these scholarly accounts. Second, I develop a framework for assessing the possibility of white racial attitude change in the World War II era by drawing on theoretical accounts of attitude change in the mid-1960s civil rights era and accounts of the effects of World War II era military service on black veterans. This leads to two testable hypotheses regarding the liberalization of white racial attitudes. After framing my inquiry, I discuss the data sets used and methods necessary to adequately work with them. I then present the results of my analysis. I conclude with a discussion of my findings and areas for future research, as well as how this study of white racial attitudes can help build a broader framework for understanding the potentially heterogeneous effects of the Second World War on American racial politics more generally.

\section{BACKGROUND}

\section{Historical Context}

Many elites in the 1940 s saw a connection between the war effort and domestic racial issues. The most famous example is Gunnar Myrdal and his mammoth study, An American Dilemma: The Negro Problem and Modern Democracy. Over the course of nearly 1,500 pages, Myrdal made the contradiction between the aims of the war and Jim Crow clear:

\begin{abstract}
This War is an ideological war fought in defense of democracy. The totalitarian dictatorships in the enemy countries had even made the ideological issue much sharper in this War than it was in the First World War. Moreover, in this War the principle of democracy had to be applied more explicitly to race. Fascism and nazism are based on a racial superiority dogma-not unlike the old hackneyed American caste theory-and they came to power by means of racial persecution and oppression. In fighting fascism and nazism, America had to stand before the whole world in favor of racial tolerance and the inalienable human freedoms. ${ }^{9}$
\end{abstract}

The book is filled with such claims. "There looms a 'Negro aspect' over all post-war problems," Myrdal proclaimed. ${ }^{10}$ Some 571 pages later, he was more confident in his phrasing: "There is bound to be a redefinition of the Negro's status in America as a result of this War."11 Myrdal's book was, according to Alan Brinkley, a "major factor in drawing white liberal

9. Myrdal, An American Dilemma, 1004.

10. Ibid., 426.

11. Ibid., 997. 
attention to problems of race-precisely because Myrdal himself discussed racial injustice as a rebuke to the nation's increasingly vocal claim to be the defender of democracy and personal freedom in a world menaced by totalitarianism." ${ }^{2}$ Although it received some scattered criticism, the nature of the book-its social scientific language, nonpartisan sponsorship, massive length, Myrdal's Europeanness-led it to seem like a definitive analysis of the American race problem in elite discourse. ${ }^{13}$

This was also perceived, in more negative terms, by certain prominent racial conservatives. Charles Wallace Collins, a Southern attorney whose 1947 book, Whither Solid South?, provided "intellectual guidance" to the Dixiecrat movement, worried that the war "offered the opportunity for the rationalization of the position of the Negro as a citizen of the United States in a time of war." ${ }^{14} \mathrm{He}$ did not view this prospect in a positive light.

Along with the general sense that the war might lead to aggregate changes in white attitudes, there was likewise a more specific belief that serving in the war would make white veterans more racially tolerant:

During the Detroit race riots in 1943 three sailors waded in to a white mob which was beating unmercifully a slender Negro youth. "He isn't doing you guys any harm. Let him alone!" one of the trio shouted as he and his companions rescued the Negro and fought back the mob.

"What's it to you?" one of the rioters snarled. "Plenty," replied the sailor. "There was a colored guy in our outfit in the Pacific and he saved the lives of two of my buddies. Besides, you guys are stirring up here at home something we are fighting to stop!"

This suggestive anecdote is drawn from NAACP leader Walter White's 1945 book, A Rising Wind. Although perhaps apocryphal-White had a tendency to capture dialogue in a manner that seems awkwardly folksy to contemporary ears-such tales nevertheless reached a wide audience and were consistent with other accounts at the time suggesting the war

12. Alan Brinkley, The End of Reform: New Deal Liberalism in Recession and War (New York: Vintage, 1995), 168-69.

13. Ibid., 169-70. For contemporaneous criticism, see, e.g., Leo P. Crespi, "Is Gunnar Myrdal on the Right Track?" Public Opinion Quarterly 9, no. 2 (1945): 201-12. Ralph Ellison also penned a notable critique that the Antioch Review declined to publish at the time. Fortunately, this was later published in a collected volume of Ellison's writing. See Ralph Ellison, Shadow and Act (New York: Vintage, 1995), 303-17.

14. Joseph Lowndes, From the New Deal to the New Right: Race and the Southern Origins of Modern Conservatism (New Haven: Yale University Press, 2008), 11. The Collins quote can be found in ibid., 22.

15. Walter White, A Rising Wind (Garden City, NY: Doubleday, Doran, 1945), 124-25. had liberalized the previously racist views of white soldiers fighting for democracy.

White shared other interesting stories as well. In England, he visited the black G.I. Liberty Clubdespite his taxi driver's insistence that he must mean the white Rainbow Club. Although designed for black soldiers, there were some white G.I.'s present as well-"the Georgia accent of one of them was thick as the mud of the Chattahoochee," according to White. The white Georgian told him he preferred the Liberty Club to any of the white clubs because he had become friends with some black soldiers who would not be welcome at the all-white alternatives. White inquired about whether these friendships would continue upon his stateside return: "Ruefully, he spread his hands, palms upward, and shrugged his shoulders. 'I don't know,' he said sadly." 16

Another white soldier recounted his experiences at the Stage Door Canteen in New York City prior to being sent overseas. The first time the soldier went there, he found black hosts and servicemen and he left in anger. But because the canteen was the standard gathering place for soldiers unfamiliar with the city, he went back several times and had a change of heart. "If we can play together, why can't we fight together?" he asked White. When informed of proposals to establish an integrated unit that white and black soldiers could volunteer to join, he replied, "I'd like to be the first to volunteer. Then I wouldn't feel like a Goddamned hypocrite when people over here ask why, in fighting a war for democracy, the United States sends over one white and one Negro army."17

However, not all of White's interviews were so positive. Many white soldiers expressed significant prejudice. Racial rumors abounded, generally started when white Americans told European locals wild tales of supposed black behavior. ${ }^{18}$ Perhaps a more interesting anecdote, however, is White's conversation with General Dwight Eisenhower. Referring to a discussion with an unnamed New York journalist, Eisenhower "almost belligerently" exclaimed to White, "He told me my first duty was to change the social thinking of the soldiers under my command, especially on racial issues. I told him he was a damned fool-that my first duty is to win wars and that any changes in social thinking would be purely incidental. Don't you think I was right?" ${ }^{19}$ Such conversations suggest

16. Ibid., 15.

17. Ibid., 36-37.

18. For a more general discussion of rumors on the home front, see Howard W. Odum, Race and Rumors of Race: Challenge to American Crisis (Chapel Hill: University of North Carolina Press, 1943). See also James T. Sparrow, Warfare State: World War II Americans and the Age of Big Government (New York: Oxford University Press, 2011), 95-100.

19. White, A Rising Wind, 63. 
the link between white military service and civil rights liberalism might not necessarily be so clear.

More academic work also connected military service to potential changes in racial attitudes. In To Stem This Tide: A Survey of Racial Tension Areas in the United States, written in 1943, Charles Johnson and his associates shared an anecdote from Evansville, Indiana, where a train conductor ordered a group of white and black soldiers from the same town to separate, but a white soldier refused the order and threatened to fight the train crew. ${ }^{20}$ In the war's aftermath, University of North Carolina sociologist Howard Odum, writing in 1948, described "a relatively large number of young college students and returning G.I.'s advocating a more liberal practice with reference to race relations" in the white South. ${ }^{21}$ These claims fit with what Walter White was telling the War Department. In an April 1944 memorandum, for instance, White described his tour of the North African and Middle Eastern Theatres of Operation, writing, "As men approach actual combat and the dangers of death, the tendency becomes more manifest to ignore or drop off pettiness such as racial prejudice.... When German shells and bombs are raining about them, they do not worry as much about the race or creed of the man next to them."22

The historiography on the relationship between World War II and black civil rights reflects the possible ambiguities of the relationship. In the 1960s, this era was referred to as the "forgotten years of the Negro revolution. ${ }^{23}$ In the strongest form of this perspective, one historian declared that "the war in many ways made the civil rights movement possible."24 More recently, historians have increasingly taken a more critical perspective on the war's relationship with civil rights. "If historians search for the roots of the civil rights movement in the wartime struggle, they will doubtlessly find something in the discordant record resembling the evidence they seek," Kevin Kruse and Stephen Tuck write. While acknowledging "the turmoil and rhetoric and bloodshed of war did indeed provide a far-reaching challenge to Southern, national and global systems of race," they argue that it "did not push racial systems in a single direction, and certainly not one moving inexorably toward greater equality." ${ }^{25}$

20. Charles S. Johnson and Associates, To Stem This Tide: A Survey of Racial Tension Areas in the United States (New York: AMS Press, 1943), 38.

21. Odum, "Social Change in the South," 244.

22. Walter White to War Department, memorandum, April 22, 1944, OF 93 in Franklin D. Roosevelt President's Official Files, 1933-1945, Franklin D. Roosevelt Library, Hyde Park, NY.

23. Richard M. Dalfiume, "The 'Forgotten Years' of the Negro Revolution," Journal of American History 55, no. 1 (1968): 90-106.

24. Pete Daniel, "Going among Strangers: Southern Reactions to World War II," Journal of American History 77, no. 3 (1990): 910.

25. Kevin M. Kruse and Stephen Tuck, "Introduction: The Second World War and the Civil Rights Movement," in Fog of War:

\section{The War, Racial Attitudes, and Historical Institutionalists}

Present-day political science scholarship has similarly made claims about the war's effects on racial attitudes, often in the background of other arguments about political institutions. Klinkner and Smith's The Unsteady March, for example, argues that war is a necessary, albeit not sufficient, condition for racial progress in the United States. In particular, they point to three factors: large-scale war requiring mobilization of black soldiers, enemies of a nature that require the government to justify the war in egalitarian rhetoric, and protest movements able to make the government at least partially live up to its justificatory rhetoric. Daniel Kryder's Divided Arsenal demonstrates how wars in American history coincide with increases in racial crowd violence and examines how the Roosevelt administration managed racial conflict to successfully execute the war. More recently, Robert Saldin's War, the American State, and Politics since 1898 offers a more general and expansive overview of how war has shaped American domestic policy, including the greater inclusion of marginalized groups. These three works all share a focus on political institutions. However, they also make several striking comments about the relationship between the war and white attitudes - without any original analysis of public opinion data. ${ }^{26}$

Klinkner and Smith claim, for example, that it is "hard to escape the conclusion" that the "Nazi menace forced at least some white Americans to begin to reexamine the racial inequalities in their midst." 27 Later, they fill in the causal processes. "The ideological demands of fighting an enemy who espoused racial hierarchies made more white Americans sensitive to the presence of racial discrimination in America," they argue. "The vision of blacks marching to claim their rights contradicted the image of America as the defender of democracy." ${ }^{28}$ Klinkner and Smith do offer some willingness to concede that white opinion in the South did not liberalize and

The Second World War and the Civil Rights Movement, ed. Kevin M. Kruse and Stephen Tuck (New York: Oxford University Press, 2012), 11-12. For a collection of essays on the role of World War II on the South more generally, see Neil R. McMillen, ed., Remaking Dixie: The Impact of World War II on the American South (Jackson: University Press of Mississippi, 1997).

26. Klinkner and Smith do refer to topline results from secondary sources. See, e.g., their reference to an Office of War Information civilian survey and a survey of white officers and noncommissioned officers described in Morris J. MacGregor and Bernard C. Nalty, Black Soldiers in World War II, vol. 5, Blacks in the United States Armed Forces: Basic Documents (Wilmington: Scholarly Resources, 1977). Klinkner and Smith, The Unsteady March, 180, 190. They also note topline results from Roper and NORC surveys. See ibid., 201. However, these surveys are cited as secondary sources, rather than subject to original analysis using proper weighting techniques.

27. Klinkner and Smith, The Unsteady March, 137.

28. Ibid., 160 . 
perhaps even hardened in its white supremacist resolve. ${ }^{29}$ But in general, their claim about a shift in white attitudes is fairly strong. This claim about public opinion affects not only their assessment of the public but also normative assessments of other actors like President Franklin Roosevelt. "Roosevelt's unwillingness to take a stronger stand on racial issues was, in hindsight, regrettable and costly," they argue. "True, white Southerners were becoming more restive, but it seems clear that in the context of the war, nationally public attitudes on race had shifted enough that he could have been more outspoken for reform." 30

While Klinkner and Smith's book contains no analysis of survey data, their account has been cited in discussions of liberalizing white attitudes. Saldin, for example, refers to Klinkner and Smith as an authority in asserting an "undeniable growth of racial liberalism linked to World War II," including shifts in mass opinion. ${ }^{31}$ Even though Klinkner and Smith's research is not centrally concerned with public opinion, it has had the effect of strengthening the view that World War II liberalized white racial attitudes. $^{32}$

Although this article focuses on the nature of white mass opinion, this tendency extends into other realms like the attitudes of white elite political actors. For instance, it is often taken for granted that the 1944 Smith v. Allwright case outlawing the white primary was motivated, at least in part, by the ideological logic of the Second World War. Yet the evidence for this claim is surprisingly lacking. The legal scholar Michael Klarman is perhaps the clearest example. While Klarman gives some credit to "Roosevelt's virtually complete recomposition of the Court," he argues this explanation is "missing something more fundamental-the significance of World War II." His argument, however, is surprisingly vague. "This is necessarily a point of speculation," he acknowledges, "because nothing in the Smith opinion or the surviving conference notes refers to the significance of the war. Still, the Justices cannot have failed to observe the tension between a purportedly democratic war fought against the Nazis, with their theories of Aryan supremacy, and the pervasive

29. Ibid., 168 .

30. Ibid., 199 .

31. Saldin, War, the American State, and Politics, 114-15.

32. Saldin's discussion of white attitudes is actually quite nuanced. He argues the war "influenced both mass opinion (at least that of the soldiers) and elite opinion," but that the latter was more important (ibid., 115). He also notes Klinkner and Smith's discussion of shifts in popular culture, which is a shift not discussed in this article. Kryder, likewise, makes assumptions about the white public, albeit somewhat more negatively than Klinkner and Smith. Kryder suggests Americans were "less familiar with the aims of the war and their relationship to democratic ideals than Myrdal believed." See Kryder, Divided Arsenal, 10. disenfranchisement of Southern blacks." 33 Klinkner and Smith make a similar argument. "The Court's decision in Smith reflected its emerging stress on the protection of civil and political rights, an emphasis influenced by the changing global context," they write. Although they acknowledge that Justice Stanley Reed, who wrote the Smith majority opinion, "made no mention of the war," they point to two sources: a New York Times correspondent, who declared the "real reason" for the Court's move against the white primary was "that the common sacrifices of wartime have turned public opinion and the Court against previously sustained devices to exclude minorities," and a 1979 book by the historian Darlene Clark Hine, which calls the white primary "one of the casualties of World War II." ${ }^{34}$ However, neither source provides direct evidence that the Smith case was affected by the war, yet they are treated as though they do. ${ }^{35}$

\section{Military Service and Racial Attitudes}

Scholarship on the attitudinal and behavioral impacts of the war on veterans, by contrast, has used public opinion data. However, it has focused almost entirely on black veterans. Christopher Parker, for example, convincingly argues that military service in the Second World War, as well as the Korean War, had a direct impact on the willingness of black veterans in the South to challenge the white supremacist status quo. ${ }^{36}$ However, there remains an open question of whether the war might have also had significant ramifications for white attitudes and political behavior. Parker argues that "we should expect black Southerners who were exposed to different, more egalitarian cultures to have begun an aggressive interrogation of white supremacy." 37 To what extent might this be

33. Michael J. Klarman, "The White Primary Rulings: A Case Study in the Consequences of Supreme Court Decisionmaking," Florida State University Law Review 29 (2001): 64. Klarman's discussion of how increases in southern legal challenges were partly a result of "the greater black militancy spawned by World War II" is more convincing (ibid., 76). Such a claim fits with Parker, Fighting for Democracy.

34. Klinkner and Smith, The Unsteady March, 193.

35. To be fair, it is of course possible that the war had an effect on the justices, but that they would not have written about it directly. In this sense, I would hesitate to argue that there was definitively no effect of the war on this or other cases. However, at the very least, such an effect is not demonstrable with the available evidence. For an analysis of the aftermath of Smith $v$. Allwright, see Robert W. Mickey, "The Beginning of the End for Authoritarian Rule in America: Smith v. Allwright and the Abolition of the White Primary in the Deep South, 1944-1948," Studies in American Political Development 22 (2008): 143-82.

36. Parker, Fighting for Democracy. For an earlier, more qualitative analysis of how southern black veterans thought about their service, see Neil R. McMillen, "Fighting for What We Didn't Have: How Mississippi's Black Veterans Remember World War II," in Remaking Dixie: The Impact of World War II on the American South, ed. Neil R. McMillen (Jackson: University Press of Mississippi, 1997), 93-110.

37. Parker, Fighting for Democracy, 95. 
true for whites who experienced these same "more egalitarian cultures"?

Studies of white veterans have been more local and specific. Jason Sokol's history of white Southern reactions to civil rights quotes individual white Southern men who, as a result of their service in the Second World War, came to learn "that freedom means more than just freedom for the white man," as one phrased it. However, Sokol suggests that such attitude changes were small, constituting "only a small fraction of white southern servicemen."38 Although Sokol's analysis is enlightening in many respects, it stops short of being generalizable by the standards of political scientists.

Perhaps the best research on white veterans is Jennifer Brooks's analysis of veterans in postwar Georgia. While many Southern black men returned from World War II determined to tear down white supremacy, Brooks suggests that the impact of military service on returning white veterans was more heterogeneous. "A small but vocal minority of southern white veterans also defined the war's meaning and their own participation in it as a mandate to implement a political freedom that applied to all Georgians," she writes. These white veterans joined returning black soldiers in their efforts. However, this push for racial equality "provoked an immediate backlash from other white veterans determined to sustain all the power and prerogatives of white supremacy."39

\section{What's Missing}

This review suggests at least two avenues for research, then. First, is the available survey evidence consistent with the argument that World War II led to an increase in white racial liberalism? Second, in the war's aftermath, were white veterans more racially liberal than their nonveteran counterparts? The next section relates these questions to theoretical frameworks for thinking about attitudinal change on race and sets out testable hypotheses to assess the war's impact on white racial attitudes.

\section{THEORETICAL FRAMEWORK}

What does it mean to ask about the effect of something like World War II? To be a useful analytical concept, "the war" must be unpacked into its constitutive elements, each of which can have different logics. There are several distinctive aspects of World War II, two of which are (1) the ideological sense of the war and (2) the massive material undertaking of the war. The former most obviously describes the anti-

38. Jason Sokol, There Goes My Everything: White Southerners in the Age of Civil Rights (New York: Knopf, 2006), 19, 20, 25.

39. Jennifer E. Brooks, Defining the Peace: World War II Veterans, Race, and the Remaking of Southern Political Tradition (Chapel Hill: University of North Carolina Press, 2004), 36. racist logic of a war against Nazism that so many have linked it to. The latter includes shifts related to wartime industrialization and military buildup, including migration related to the former and personnel needs related to the latter. Industrial and military institutions were faced with new pressures as a result, which opened new possibilities and points of leverage for the civil rights movement, especially on job discrimination issues.

While acknowledging these political-economic changes (which I discuss further in the conclusion), this article considers white racial attitudes as a vantage point from which to assess the war's potential ideological logic: Did a war against Nazism and fascism lead to a rethinking of the racial status quo for white Americans on the home front? ${ }^{40}$ To build a framework for assessing attitude change, I first review theoretical debates about the catalysts for aggregate white racial attitude shifts in the 1960s civil rights era. I then consider Parker's account of changes in the attitudes of black veterans who served in World War II and Korea. This leads me to develop a framework for thinking about the possibility of aggregate white racial attitude shifts in the World War II era, as well as what should be expected regarding the racial attitudes of white veterans. Based on this framework, I set out two testable hypotheses.

\section{White Racial Attitude Shifts in the Civil Rights Era}

Scholars have debated whether opinion shifts in the 1960s were elite-driven or more bottom-up. ${ }^{41}$ Others have examined factors like childhood socialization and generational replacement. ${ }^{42}$ However, I focus here on the role of the national media. Many scholars

40. Of course, the realities of political-economic change on the home front could have shaped white attitudes as well, and I consider this at various points throughout. I also return to a broader discussion of political-economic changes in the conclusion.

41. For the former, see Edward G. Carmines and James A. Stimson, Issue Evolution: Race and the Transformation of American Politics (Princeton, NJ: Princeton University Press, 1989); John R. Zaller, The Nature and Origins of Mass Opinion (New York: Cambridge University Press, 1992). For a discussion of the latter, see Taeku Lee, Mobilizing Public Opinion: Black Insurgency and Racial Attitudes in the Civil Rights Era (Chicago: University of Chicago Press, 2002).

42. For historical accounts of how children were socialized in the Jim Crow South, see Jennifer Ritterhouse, Growing Up Jim Crow: How Black and White Southern Children Learned Race (Chapel Hill: University of North Carolina Press, 2006); and Kristina DuRocher, Raising Racists: The Socialization of White Children in the Jim Crow South (Lexington: University Press of Kentucky, 2011). Ritterhouse describes the etiquette of race relations-etiquette, she notes, inherently "involves at least some coercion"-learned by children in the Jim Crow South, while DuRocher points to an emphasis on violence (e.g., young white children attending lynchings). For a discussion of the role of generational replacement in trends in racial attitudes, see Howard Schuman, Charlotte Steeh, Lawrence Bobo, and Maria Krysan, Racial Attitudes in America: Trends and Interpretations, rev. ed. (Cambridge, MA: Harvard University Press, 1997). 
of trends in public opinion point to the role of the media as a catalyst for change in white racial attitudes. Howard Schuman et al., for example, refer to "many Northern whites who witnessed, through television and other media, the brutality of Bull Connor and other white supremacists." They note that public opinion trends fit with historical accounts that "speak of the rethinking and searching of conscience that were prompted by the events of 1963." 43

Benjamin Page and Robert Shapiro also note this "pro-civil rights opinion trend," and likewise suggest "a good many events of the late 1950s and early $1960 \mathrm{~s}$, heavily covered by the mass media, surely played a part." A4 Although they acknowledge "the general hostility of Americans to protests and demonstrations," they argue that "televised images of Southern policemen beating peaceful black demonstrators and setting dogs upon them galvanized the nation. There can be little doubt that the civil rights movement and Southern whites' highly visible 'massive resistance' to it had a major impact on public opinion." ${ }^{45}$ Media coverage-especially of violent white resistance to protesters-is seen as key by both of these major accounts of attitudinal trends.

Paul Kellstedt offers the most systematic study of the relationship between aggregate racial attitude change and the quantity and tenor of media coverage. He shows how the number of stories about race and civil rights in Newsweek spiked beginning in 1963, when there were 152 such stories. This continued for several years during the height of the 1960s civil rights movement. Kellstedt also points to the tenor of the coverage, demonstrating how this era saw media coverage that framed the debate in egalitarian, rather than individualistic, messages. ${ }^{46}$ This, he argues, was a hospitable environment for the growth of racial liberalism in aggregate public opinion. The role of the media is absolutely central for Kellstedt. Fitting with Schuman et al. and Page and Shapiro, he notes, "Most of the key events of the movement, after all-desegregation battles in Little Rock and elsewhere, bus boycotts, freedom rides-took place in communities that few non-southerners would have known about were it not for the national press." ${ }^{47}$

43. Schuman et al., Racial Attitudes in America, 27-28.

44. Benjamin I. Page and Robert Y. Shapiro, The Rational Public: Fifty Years of Trends in Americans' Policy Preferences (Chicago: University of Chicago Press, 1992), 76. It should be noted that even in the 1960 s, attitudinal shifts were gradual. For a visualization of trends over time in racial attitudes over many decades, see ibid., 70-78.

45. Page and Shapiro, The Rational Public, 77. See also James P. Winter and Chaim H. Eyal, "Agenda Setting for the Civil Rights Issue," Public Opinion Quarterly 45, no. 3(1981): 376-83. They argue the place of civil rights on the public agenda correlates with coverage of civil rights on the front page of the New York Times in the period 1954-1976.

46. Kellstedt, The Mass Media, 31-37.

47. Ibid., 5 .
The 1960s civil rights era is a useful comparison to the World War II era because it highlights important historical differences, one of which is the variable role of the media in covering and framing civil rights protest. Compared to the mid-1960s, the national media in the World War II era largely did not discuss racial inequality. ${ }^{48}$ There were of course some exceptions-discussion of the Fair Employment Practices Committee (FEPC) and the Detroit race riot being two examples-but these were not the norm, nor did they fit into the egalitarian tenor emphasized by Kellstedt. As such, any theoretical tensions between American ideals of egalitarianism and the reality of Jim Crow racism were not primed for most white Americans. Thus, while it is possible that the ideological logic of the war led to a rethinking of racial attitudes, it is also possible this tension was perceived more by elites than the white mass public more generally. Accounts of the war's relationship with civil rights have tended to emphasize the plausibility of the ideological logic argument, rather than thinking through the extent to which the broader public recognized the validity of such an argument or not.

\section{Black Veterans and Civil Rights Attitudes}

Veterans are especially likely to be affected by wartime. Most veterans serve during what has been called "the impressionable years" of their late teens and early twenties, when attitudes of all sorts are most likely to crystallize. ${ }^{49}$ Parker analyzes the "radicalizing experience" of military service for Southern black men in particular. ${ }^{50} \mathrm{He}$ presents a theoretical framework to explain black veterans' attitudes and behavior. Building on the citizen-soldier tradition in republican political thought, Parker examines how black veterans interpreted the meaning of their military experience, then argues this led to a new belief system he calls "black republicanism."

48. This is, of course, quite the opposite of black newspapers, which regularly highlighted the tensions between a war for democracy and racism on the home front. Whites, however, were not attuned to this coverage. For a discussion of black newspapers and protest movements generally, see Charlotte G. O'Kelly, "Black Newspapers and the Black Protest Movement: Their Historical Relationship, 1827-1945," Phylon 43, no. 1 (1982): 1-14.

49. Parker, Fighting for Democracy, 72-73. See also Howard Schuman and Jacqueline Scott, "Generations and Collective Memories," American Sociological Review 54, no. 3 (1989): 359-81. For a more general discussion of the impressionable years hypothesis, see Duane F. Alwin, Ronald L. Cohen, and Theodore M. Newcomb, Political Attitudes over the Life Span: The Bennington Women after Fifty Years (Madison: University of Wisconsin Press, 1991); Duane F. Alwin and Jon A. Krosnick, "Aging, Cohorts, and the Stability of Sociopolitical Orientations over the Life Span," American Journal of Sociology 97, no. 1 (1991): 169-95.

50. Parker, Fighting for Democracy, 61. He relates this directly to Foner's discussion of black military service in the Civil War and its effects on political behavior during Reconstruction. See Eric Foner, Reconstruction: America's Unfinished Revolution (New York: Harper and Row, 1988). 
In many ways, this framework is specific to the experience of black soldiers. For instance, Parker highlights the tension between how black soldiers were treated and the ideals for which they were fighting. White soldiers were simply not treated with the same sort of second-class status. However, his discussion of the effects of being deployed overseas raises interesting questions about effects on white soldiers. Parker, though, clearly distinguishes between white and black soldiers in this discussion. "For white servicemen, travel overseas resulted in increased selfawareness," he writes. "For black servicemen, especially from the South, experiencing life overseas went beyond self-awareness. Deployment during the Second World War and the Korean War exposed well over a million black Southerners-who were accustomed to discrimination and oppressive conditions-to a model of race relations in which the indigenous, dominant group often treated them with a measure of respect." This, he argues, gave them additional motivation "to question the legitimacy of white supremacy."

Although they were differentially situated, white soldiers were nonetheless similarly exposed to such variation in race relations. As Parker notes in a general sense, "exposing people to new patterns of social relations and cultural norms tends to expand their worldview by enlarging their perceptions of what is possible." This logic, he argues, leads to an expectation that "black Southerners who were exposed to different, more egalitarian cultures" would "have begun an aggressive interrogation of white supremacy." 52 However, the extent to which such exposure might also have shifted white attitudes merits some examination as well.

White soldiers experienced the war differently than whites on the home front. Like black soldiers, white soldiers were also exposed to "more progressive cultures elsewhere," where "dominant groups often treated [black soldiers] with a measure of respect." We should not expect "an aggressive interrogation of white supremacy," as Parker's framework predicts for black veterans. However, insomuch as the experience could have "enlarg[ed] their perceptions of what is possible," it might have at least led to new questions. It seems plausible, then, that exposure to new possibilities could have led at least some white veterans to be more open to racial liberalism. If any whites were to be liberalized as a result of the war, veterans would seem to have been very plausible candidates. While all whites were in some sense "treated" by the war, those who served in the military were certainly affected more directly.

51. Parker, Fighting for Democracy, 72.

52. Ibid., 95.

\section{Assessing White Racial Attitude Change During World War II}

This discussion leads to two hypotheses, which I assess in the remainder of this article. Here I briefly describe each hypothesis and discuss the grounding for either a positive or null outcome. I call the first the racial liberalization hypothesis:

Racial liberalization hypothesis: World War II led to liberal shifts in white attitudes toward race and civil rights.

The racial liberalization hypothesis is simply an explicitly stated version of the common view. Not everyone believes this-Kryder's book suggests that it is likely incorrect-but it is intellectually predominant. It is also entirely plausible. If the racial liberalization hypothesis is correct, the most likely mechanism linking the war to white racial attitudes is the ideological logic of a war against Nazi racism undermining elite justifications of Jim Crow. Certainly, civil rights activists-advocating as they did a Double- $\mathrm{V}$ campaign for victory at home and abroad-found this logic compelling. ${ }^{53}$ In the aftermath of the 1943 Detroit race riot, an editorial in The Nation declared, "We cannot fight fascism abroad while turning a blind eye to fascism at home. We cannot inscribe our banner 'For democracy and a caste system'." 54 Such statements gave the institutional support of white liberals to similar claims being made by the black civil rights movement.

It is often assumed that many ordinary white Americans saw this connection as well. Along with the previous examples, such accounts can be found in sources as far-flung as constitutional law books. Writing of World War II, Alfred H. Kelly asserts,

The egalitarian ideology of American war propaganda, which presented the United States as a champion of democracy engaged in a death struggle with the German racists, created in the minds and hearts of most white people a new and intense awareness of the shocking contrast between the country's too comfortable image of itself and the cold realities of American racial segregation. ${ }^{55}$

This claim is simply presented as background to a discussion of Brown $v$. Board; it is indicative of a

53. For a discussion of the Double-V campaign, see Harvard Sitkoff, "Racial Militancy and Interracial Violence in the Second World War," Journal of American History 58, no. 3 (1971): 668-81; Neil A. Wynn, The Afro-American and the Second World War, rev. ed. (New York: Holmes \& Meier, 1993); Jonathan Rosenberg, How Far the Promised Land? World Affairs and the American Civil Rights Movement from the First World War to Vietnam (Princeton, NJ: Princeton University Press, 2005).

54. Cited in Maria Hohn, "We Will Never Go Back to the Old Way Again': Germany in the African-American Debate on Civil Rights," Central European History 41 (2008): 616.

55. Kelly, "The School Desegregation Case," 312. 
widespread belief that the racial liberalization hypothesis is accurate in popular understandings of the war.

However, there is also theoretical grounding for a null or even negative result. Southern newspaper columnist John Temple Graves, for example, wrote in 1942, "They have invited their followers to think in terms of a Double V-for-Victory-victory in battle with Hitler and victory in battle at home. Victory, unhappily, doesn't work that way." article, while detailing improvements in the conditions of black Southerners during the war, he noted the decline of lynchings, but warned, "Unhappily the number may increase now as a result of the agitations of the white man against the black and the black against the white." ${ }^{57}$ Indeed, it is possible to imagine Southern whites fearing that the Double-V campaign was being persuasive, and thus doubling down on their white supremacist resolve.

Further, the relative dearth of national media coverage related to race and civil rights politics would imply that a framework like that of Kellstedt's would not apply as well to the World War II period. While the ingredients for an egalitarian media framing were there, the national media chose not to put it together. Many whites, therefore, simply might not have connected the dots. As such, a null result would be theoretically consistent with Kellstedt's media-centric model. ${ }^{58}$

The second hypothesis is a variation on the racial liberalization hypothesis focused on distinctions between veterans of the war and those who did not serve directly:

\section{Racial liberalization hypothesis for veterans: World War II liberalized the racial attitudes of white veterans, relative to their nonveteran counterparts.}

The racial liberalization hypothesis for veterans shifts the focus from temporal shifts in the aggregate white public to differences between otherwise similar veterans and nonveterans. Of course, nonveterans were still "treated" by the war, but indirectly rather than directly. Compared to whites who experienced the war on the home front, whites who served in the military might have felt more closely connected with the anti-Nazi crusade; they might also have encountered black soldiers and changed their opinions about at least some aspects of race relations. Their exposure to the sorts of relatively more egalitarian cultures in places like France and England that Parker points to as inspiring black resistance might have likewise

56. John Temple Graves, "The Southern Negro and the War Crisis,” Virginia Quarterly Review 18, no. 4 (1942): 501.

57. Ibid., 514.

58. For an account of how white journalists began covering civil rights to a much greater extent during the civil rights era of the 1950s and 1960s, see Gene Roberts and Hank Klibanoff, The Race Beat: The Press, the Civil Rights Struggle, and the Awakening of a Nation (New York: Knopf, 2006). made white soldiers rethink the norms of their own country.

Theoretical grounding for a null result here can be found in arguments that white soldiers were fighting to defend their way of life-white supremacy and all-rather than something more transformative. Many white veterans simply wanted to return home and resume life exactly as they had left it. "That often meant supporting Jim Crow as staunchly as ever," Sokol writes. "Many believed they had fought to defend, not overturn, racial customs." ${ }^{29}$ Parker, similarly, notes that many white soldiers brought their racial views with them, rather than being amenable to new social norms. Indeed, many white soldiers from outside the South were exposed to Southern Jim Crow for the first time in the military, as the military segregated soldiers by race. The extent to which various contradictory outcomes are entirely plausible suggests the merits of carefully assessing the evidence for each variant of the racial liberalization hypothesis.

A quick aside is in order regarding the focus on whites. This article chooses to restrict the analysis to whites for two reasons, one substantive and one methodological. Substantively, the broad question is about whether racist views can be brought into question by an external shock like World War II. Focusing on whites makes sense in this regard. For the veterans analysis, analyzing white veterans complements the analysis of black veterans offered by Parker. Methodologically, the 1940s survey data undersampled black respondents generally, but especially undersampled Southern black respondents. Since three-fourths of all African Americans lived in the South in the 1940 s, this is a substantial methodological limitation for any analysis of black public opinion. Given this substantive focus and the methodological deficiencies of quota sampling, I argue that a focus on white attitudes is justified. Pairing the results presented here with other work-especially comparing the white veterans results with Parker's analysis of black veterans-will result in a fuller depiction of racial attitudes more generally.

\section{DATA AND METHODOLOGY}

To assess the first hypothesis, I used public opinion surveys from 1937 to $1950 .{ }^{60}$ I examined measures of prejudice and policy preferences that were repeated at multiple time points. This involves six questions about general racial attitudes and policy questions about lynching and the poll tax. ${ }^{61}$ I discuss the question wordings in the relevant sections.

59. Sokol, There Goes My Everything, 20, 23.

60. These data sets were obtained from the iPoll Databank, Roper Center, Cornell University, http://ropercenter.cornell. edu/ipoll-database/.

61. These represent the primary civil rights policy issues of the 1930 s and early 1940s. For an analysis of legislative action on these 
To correct for the known biases of the quota sampling procedure employed at the time, I used the method advocated by Adam Berinsky and Eric Schickler. This effectively involves breaking the sample into demographic subgroups and using census data to weight each subgroup according to their share of the population. ${ }^{62}$ This is discussed along with question wordings throughout. To assess aggregate shifts, I made a series of temporal comparisons using the weighted numbers. If the racial liberalization hypothesis is correct, then the liberal position on each issue should increase over time. However, if there is no change-or if there is actually an increase in the conservative position-then the racial liberalization hypothesis is not supported. ${ }^{63}$

To assess the second hypothesis, I examined public opinion surveys from two distinct time periods: the mid- to late 1940s, to assess the more immediate impact of the war, and the early 1960 s, to assess the longer-term impact. The methodological challenge here was finding surveys that ask about race or civil rights and also identify veteran status. The first section used two surveys to analyze the first hypothesis, but in a slightly different way. I used an additional

and other civil rights issues of the era, see Jeffrey A. Jenkins and Justin Peck, "Building Toward Major Policy Change: Congressional Action on Civil Rights, 1941-1950," Law and History Review 31, no. 1 (2013): 139-98. See also Eric Schickler, Kathryn Pearson, and Brian D. Feinstein, "Congressional Parties and Civil Rights Politics from 1933 to 1972," Journal of Politics 72, no. 3 (2010): 672-89. For an analysis of congressional action in the lead-up to the World War II era, see Jeffrey A. Jenkins, Justin Peck, and Vesla M. Weaver, "Between Reconstructions: Congressional Action on Civil Rights, 1891-1940," Studies in American Political Development 24, no. 1 (2010): 57-89. One limitation to these policy questions is that they are sectional in nature, primarily referencing racial politics in the southern states. After presenting the results, I return to this issue in the discussion. Readers might also expect discussion of the proposed Soldier Voting Act, as it relates directly to the connection between the war and the claims of civil rights groups. A question about giving black soldiers ballots as part of the congressional soldier voting debate was indeed asked in 1944. However, this question was never repeated, so it is not possible to assess over time change.

62. Adam J. Berinsky, "American Public Opinion in the 1930s and 1940s: The Analysis of Quota-Controlled Sample Survey Data," Public Opinion Quarterly 70, no. 4 (2006): 499-529. For more detailed instructions, see Berinsky and Schickler's supplementary files on the iPoll website (http://ropercenter.cornell.edu/ipolldatabase/).

63. Expectations for effect size can be thought of in two ways. First, it is interesting to see if any change at all occurred. This would be a rudimentary test of the racial liberalization hypothesis. If no change at all occurs, at least on certain measures that is a useful rebuttal in itself. However, if there is a shift on some measures, how big should the shift be? On the one hand, even during the civil rights era of the 1960s, Kellstedt points out that shifts were gradual. On the other hand, looking at white attitudes in the World War II era means starting at a lower point on the trajectory. As will be soon be described, expressed white racial prejudice in survey data is often shockingly high. This allows for the possibility of larger shifts (because the status quo is so low) especially on measures of basic prejudice. survey that asked about military integration. I then moved ahead in time and used the Negro Political Participation Study, a survey of black and white Southerners-defined as the former Confederate states-conducted in 1961. This study merits further introduction. The Negro Political Participation Study was conducted by principal investigators Donald Matthews and James Prothro at the University of North Carolina. ${ }^{64}$ This survey uses the more modern ANES (American National Election Studies) sample design. Thus, while it is limited by the lack of a non-Southern comparison group, it does not face the limitations of the quota-controlled samples used in the previous surveys. This is the same survey used by Parker, who focused on the black sample. I utilized the white sample to address the questions stated earlier. I discuss the question wordings in the relevant sections.

Methodologically, my goal here was to estimate the relationship between veteran status and racial attitudes, controlling for other factors. ${ }^{65}$ I opted to run regressions on the male sample only. I argue that this makes clear theoretical sense-while some women served in units like the Women's Army Corps, the battles of World War II were fought almost entirely by men-although it does have the methodological shortcoming of lowering the number of observations in the models. I also restricted the sample by age to focus on those who could have plausibly been veterans. To determine what age range to use, I looked at the age and veteran status cross-tabs. For the models using the 1946 data set, I analyzed only those individuals age 40 and below. For the 1948 data sets, I used age 45 as the cutoff. For the 1961 data set, I looked only at those between 38 and 65 to best assess World War II veterans. This, too, lowered the number of observations, but it also reduced the possibility that veteran status is simply capturing an age effect.

Education-necessarily controlled for because of sampling concerns in the 1940s data sets-takes on additional importance when studying veterans, especially in the later time period. ${ }^{66}$ The 1961 cross-tabs

64. This data set was obtained from the Inter-University Consortium for Political and Social Research (ICPSR) at the University of Michigan, ICPSR, http://www.icpsr.umich.edu/icpsrweb/ ICPSR/. See also Donald R. Matthews and James W. Prothro, Negroes and the New Southern Politics (New York: Harcourt, Brace \& World, 1966).

65 . This article examines relatively immediate effects of the war (with the exception of an examination of white veterans in 1961). Longer-term effects-and effects of the sort that cannot be identified with survey data-are still possible. Another open question is whether any observed effects were immediate but then decayed over time or whether effects were more permanent. Unfortunately, the questions I am able to analyze in the late 1940s were not asked in the 1960s. However, I argue that looking at the available survey evidence is still a useful analytical perspective that can provide an important empirical baseline.

66. Berinsky suggests using the weighting variables as explanatory variables in regression models. Berinsky, "American Public 
are suggestive. In the white sample used here, 26 percent of respondents had some college experience, and 25 percent had served in the military. But among the 25 percent with military service, a much larger 39 percent had some college experience, compared with only 21 percent of nonveterans. ${ }^{67}$ This is likely largely due to the effects of the Servicemen's Readjustment Act of 1944-the G.I. Bill-which substantially aided white veterans in attending college. ${ }^{68}$

\section{RESULTS: RACIAL LIBERALIZATION HYPOTHESIS}

This section assesses the first hypothesis, that World War II led to a liberalization of white racial attitudes in the aggregate. If this is correct, we should see a liberal shift in racial attitudes, both prejudice and policy. I also examined subgroup variation related to region and size of place to further assess the aggregate trends. ${ }^{69}$ I found that while there were slight

Opinion in the 1930s and 1940s," 518. For more experimentally minded readers, I address concerns about posttreatment bias in the online appendix.

67. These differences are statistically significant.

68. While it was vastly beneficial for whites, empirical analysis demonstrates differential effects of the G.I. Bill on educational attainment between northern and southern black veterans, with little effect on collegiate outcomes for black veterans in the South. Sarah Turner and John Bound, "Closing the Gap or Widening the Divide: The Effects of the G.I. Bill and World War II on the Educational Outcomes of Black Americans," Journal of Economic History 63, no. 1 (March 2003): 145-77. This was not entirely unexpected in the immediate aftermath of the G.I. Bill's passage. Writing for the American Council on Race Relations at the end of the war, William Caudill predicted that "the white GI will be considered first a veteran, second and incidentally a white man; the Negro GI will often be considered first a Negro, second and incidentally a veteran," quoted in David H. Onkst, "First a Negro ... Incidentally a Veteran': Black World War Two Veterans and the G. I. Bill of Rights in the Deep South, 1944-1948," Journal of Social History 31, no. 3 (1998): 533. More generally, see the debate between Katznelson and Mettler regarding the G.I. Bill's potentially differential impact by race in Ira Katznelson, When Affirmative Action Was White: An Untold History of Racial Inequality in Twentieth-Century America (New York: W. W. Norton, 2005); Suzanne Mettler, Soldiers to Citizens: The G.I. Bill and the Making of the Greatest Generation (New York: Oxford University Press, 2007); Ira Katznelson and Suzanne Mettler, "On Race and Policy History: A Dialogue about the G.I. Bill," Perspectives on Politics 6, no. 3 (2008): 519-37.

69. Studying regional variation raises the complicated question of how to define the South. Following Berinsky and Schickler, I define the South here as the eleven states of the former Confederacy plus Kentucky and Oklahoma. See, for example, Eric Schickler, "New Deal Liberalism and Racial Liberalism in the Mass Public, 1937-1968," Perspectives on Politics 11, no. 1 (2013): 75-98. This is slightly more expansive than the traditional 11-state definition advocated by V. O. Key and slightly less expansive than the broader definition advocated by Ira Katznelson and colleagues. For the original justification of an eleven-state South, see V. O. Key, Jr., Southern Politics in State and Nation (Knoxville: University of Tennessee Press, 2006; originally published in 1949), 11. For contemporary examples following in this tradition, see Earl Black and Merle Black, Politics and Society in the South (Cambridge, MA: Harvard University Press, 1987); Seth C. McKee and Melanie J. Springer, "A Tale of 'Two Souths': White Voting Behavior in Contemporary Southern liberal shifts in racial prejudice, this was largely not the case for policy attitudes. White opposition to federal anti-lynching legislation actually seems to have grown during the war, and there was little discernible change on the poll tax.

\section{Racial Prejudice, 1943-1946}

In 1944, the National Opinion Research Center (NORC) administered "Survey \#1944-0225: Attitudes Toward Negroes," a national survey of white attitudes. ${ }^{70}$ The sample comprised 2,521 national white adults who were interviewed face to face. While other surveys asked a question here and there about race in the midst of other inquiries, this survey was entirely about race. The results provide a unique look at white attitudes in the middle of World War II. This particular survey made a number of people uncomfortable. In December 1944, a confidential report summarizing the results was sent to seventy-five people asking for comments on how it might be used in a constructive manner and whether it would be advisable to release the numbers into general distribution. Later, the results were in the process of being prepared for publication by the American Council on Race Relations, but the council was concerned about a preliminary release. "The danger of publishing such figures, without due caution and interpretation," they argued, "lies in the fact that many persons reading the results of the poll would mistake figures published for actual facts."11

Six of the questions from this survey were repeated on a single occasion. While this is not an ideal number of data points from a contemporary perspective, it is a goldmine by the standards of 1940s survey research. This section compares the aggregate and regional numbers between $t_{1}$ and $t_{2}$ to offer some assessment of change over time. Assessing any potential shift from 1943 to 1944 might be of some inherent interest, but unfortunately it does not allow for a wartime and postwar comparison. The 1944 and

Elections," Social Science Quarterly 96, no. 2 (2015): 588-607; Robert Mickey, Paths out of Dixie: The Democratization of Authoritarian Enclaves in America's Deep South, 1944-1972 (Princeton, NJ: Princeton University Press, 2015); Steven White, "The Heterogeneity of Southern White Distinctiveness," American Politics Research 42, no. 4 (2014): 551-78. For a justification of a more expansive definition, see Sean Farhang and Ira Katznelson, "The Southern Imposition: Congress and Labor in the New Deal and Fair Deal," Studies in American Political Development 19 (2005): 1-30; Melanie Springer, "Defining 'the South' (Is Not a Straightforward Matter)," (paper presented at the 2011 meeting of the State Politics and Policy Conference, Hanover, NH); David A. Bateman, Ira Katznelson, and John Lapinski, "Southern Politics Revisited: On V. O. Key's 'South in the House," Studies in American Political Development 29, no. 2 (2015): 154-84.

70. This data set was obtained from the iPoll Databank, Roper Center, Cornell University, http://ropercenter.cornell.edu/ipolldatabase/.

71. Jean Converse, Survey Research in the United States: Roots and Emergence 1890-1960 (Berkeley: University of California Press, 1987), 312-13. 
1946 comparison does offer this, and fortunately most of the questions were repeated at this point.

A good-living question ("Do you think Negroes have the same chance as white people to make a good living in this country?") was previously asked in a November 1943 survey titled "Postwar Problems, Old Age Pension, Public Schools and Free Speech."72 This survey interviewed 2,560 national adults face to face. Five other questions were repeated in a May 1946 survey, titled "Minorities; United Nations." ${ }^{2}$ This survey interviewed 2,589 national adults face to face. There was a question about fair treatment ("Do you think most Negroes in the United States are being treated fairly or unfairly?"), jobs ("Do you think Negroes should have as good a chance as white people to get any kind of job, or do you think white people should have the first chance at any kind of job?"), blood ("As far as you know, is Negro blood the same as white blood, or is it different in some way?"), intelligence ("In general, do you think Negroes are as intelligent as white peoplethat is, can they learn just as well if they are given the same education?"), and having a black nurse ("If you were sick in a hospital, would it be all right with you if you had a Negro nurse, or wouldn't you like it?"). The blood question might seem strange at first, but it actually relates quite directly to the war effort: the Red Cross at this time segregated donations-storing black blood separately from white blood-even during total war. ${ }^{74}$ Weights were constructed following Berinsky and Schickler's approach. $^{75}$

These questions provide different vantage points on attitudinal change during the war. The good-living and fair-treatment questions involve respondents making an assessment of conditions. As such, their meaning is more ambiguous. The objective answer is "no," but increases in the "yes" answer during the war might reflect a perception that things are getting better, if not equitable. As such, these two questions are not ideal for testing the racial liberalization hypothesis, but are still of general historical interest. The jobs question, by contrast, is normative. It does not ask whether the respondent thinks African Americans have the same chance as white people to

72. This data set was obtained from the iPoll Databank, Roper Center, Cornell University, http://ropercenter.cornell.edu/ipolldatabase/.

73. This data set was obtained from the iPoll Databank, Roper Center, Cornell University, http://ropercenter.cornell.edu/ipolldatabase/.

74. Thomas A. Guglielmo, “'Red Cross, Double Cross': Race and America's World War II-Era Blood Donor Service," Journal of American History 91, no. 1 (2010): 63-90.

75. I calculated a thirty-two-category eduWhites weight for the 1943 data set. However, I was only able to calculate a twenty-four-category eduWhites weight for the 1946 data set, as I was unable to distinguish between whites who attended high school and whites who actually graduated (these two groups are thus lumped together). get a job, but rather whether they should have the same chance or not. As such, only an increase in the "yes" answer should be interpreted as a growth of racial liberalism. The questions about blood, intelligence, and having a black nurse tap more into general prejudice. The blood question, in particular, is an extreme case that taps into forms of biological racism common in the day. Here, too, an increase in affirmative answers should be taken as evidence of growing liberalism. Results should be interpreted with care, however, since it is not possible to look at the average of multiple polls, but simply two data points. As such, these results should be seen as suggestive rather than definitive.

Three prejudice measures are consistent with the racial liberalization hypothesis. Whites became more likely to say African Americans should have the same chance at a job, rising from 38 percent to 45 percent. Northern support for equal opportunity increased from 46 percent to 52 percent; Southern support increased from 15 percent to 25 percent. Whites also became more likely to say black blood was the same, with the number increasing from 31 percent to 40 percent. The number saying it was different was effectively constant, moving from 35 percent to 33 percent. However, “don't know" responses dropped from 34 percent to 28 percent. In the North, whites moved from 34 percent to 42 percent saying it was the same. In the South, whites moved from only 20 percent saying it was the same to 32 percent saying so. Finally, whites became more likely-moving from 45 to 54 percent-to say black people were as intelligent as white people. However, this shift is almost entirely non-Southern. In the South, 30 percent of whites said yes in 1944 compared to 31 percent in 1946. In the North, however, this number increased from 50 percent in 1944 to 61 percent in 1946.

However, one prejudice measure is not consistent with the racial liberalization hypothesis. The question about having a black nurse actually saw a slight decrease in support, from 50 percent of whites saying they would be okay with this in 1944 to 46 percent in 1946. This seems primarily driven by Northern whites, where support dropped from 56 percent to 51 percent, while moving only from 32 percent to 30 percent in the South.

Finally, white opinion seems relatively constant for the two questions asking for an assessment of social conditions. The percentage of whites who said they thought African Americans had the same chance as whites to make a good living was roughly constant from 1943 to 1944 , increasing from 52 percent to 54 percent. $^{76}$ White assessments of whether African

76. If all extraneous responses, including "don't know," are dropped, it does increase from 53 to 60 percent, but this likely overstates the shift. 
Americans were being treated fairly likewise remained constant from 1944 to 1946 , at 63 percent in both years.

A comparison of rural Southerners and urban residents in the Northeast also illuminates relevant subgroup differences. In many cases, the decreases in racial prejudice seem to reflect rural Southern whites going from "extremely prejudiced" to "slightly less prejudiced." While only 10 percent of whites in the most rural areas of the South expressed support for equal job opportunities in 1944, by 1946 this number had risen to 25 percent-a sizable increase percentage-wise, albeit still a minority viewpoint. Similarly, notions among this group of white Southerners that black blood is biologically the same as white blood increased from 19 percent in 1944 to 38 percent in 1946. The changes in the urban Northeast were much smaller.

Overall, there is some evidence for the racial liberalization hypothesis with respect to the racial prejudice measures, although there was a conservative shift on the nurse question. There are, however, clear limitations to this analysis. Two data points are less than ideal, especially since there is no clear before and after. Having a prewar comparison case would be preferable. Fortunately, the two policy issues that follow are better in this regard.

\section{Policy I: Federal Anti-Lynching Legislation, 1937-1950}

I next turn to two policy areas with more available data points: anti-lynching legislation and abolition of the poll tax. I start with an assessment of changing white attitudes on federal intervention in state lynching cases. Lynching was raised as a national political issue by civil rights organizations like the NAACP. As William Hastie and Thurgood Marshall argued during the war, "the recent outbreaks of mob violence again emphasize the fact that only Federal action will free us from lynchings and the threat of lynching."77 Federal anti-lynching legislation was often proposed, but never successfully passed in the Senate (although it did pass in the House of Representatives). Such legislation was a challenge to Roosevelt's congressional New Deal alliance. Roosevelt and his congressional supporters "tailored New Deal legislation to southern preferences," according to Ira Katznelson et al., trading maintenance of Southern Jim Crow for Southern support for New Deal economic legislation. This meant that not even "the most heinous aspects of regional repression, such as lynching, [could be] be brought under the rule of law."78 Yet for many politicians outside the South, black migration meant that

77. William H. Hastie and Thurgood Marshall, "Negro Discrimination and the Need for Federal Action," Law Guild Review 2, no. 6 (1942): 21.

78. Ira Katznelson, Kim Geiger, and Daniel Kryder, "Limiting Liberalism: The Southern Veto in Congress, 1933-1950," Political Science Quarterly 108, no. 2 (1993): 297. "black political power was becoming an unavoidable

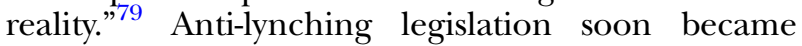
more than the sum of its parts, effectively serving as a symbol for racial conservatives of the meddling of Northern liberals in the white South's affairs.

To assess white attitudes toward federal antilynching legislation, I looked at Gallup questions about federal intervention in state lynching cases, which were asked before and after-although, interestingly, not during - the war. While Schickler discarded the "don't know" responses to create dichotomous response categories in his analysis of the prewar lynching questions, I decided to leave the "don't know" responses in to allow for a valid third category of uncertainty. As will be discussed momentarily, this helps to assess prewar and postwar shifts in the opposition category. I divided opinion in each survey into support, opposition, and don't know. I used the best possible survey weight to correct for the biases of the sampling procedure. ${ }^{80}$

A word of caution is in order regarding question wordings. While the analysis presented here is consistent with evidence regarding the poll tax (which provides a useful robustness check, as there is no substantial variation in question wording there), Gallup's questions about lynching are indicative of some of the weaknesses of early survey research. The questions can basically be divided into four groups. The first three questions, all from 1937, asked quite simply whether Congress should pass a law making lynching a federal crime. The next three questions, asked from 1937 to 1940, asked whether the federal government should have the authority to fine and imprison local authorities who do not protect against a lynch mob, which is a much more specific and severe description. In the postwar period, from 1947 to 1950, Gallup returned to a more general question, asking, with only very slight variations, something along the lines of, "At present, state governments deal with most crimes committed in their own state. In the case of a lynching[,] do you think the Federal Government should have the right to step in and deal with the crime-or do you think this should be left entirely to the state

79. George C. Rable, "The South and the Politics of Antilynching Legislation, 1920-1940," Journal of Southern History 51 (1958): 209.

80. For the postwar questions, this means calculating the eduWhites weight. However, the prewar surveys are more limited. Making the best of the available information, I used profWhites weights for the January 1937, November 1937, and January 1940 data sets; I used phoneBlack weights for the August 1937, October/November 1937, and December 1937 data sets. Weights for the prewar questions were previously computed by Schickler. I calculated the postwar weights myself. Differences in weights are necessitated by differences in available information in surveys from different time periods. However, it is unlikely this has a sizable effect, substantively. While the weighted figures are technically more accurate than unweighted ones, the substantive difference between them is generally small. 
government?" There is one outlier in the question wording, however. The 1947 question asks whether the federal government should be able to step in only "if the State Government doesn't deal with it justly." This concluding qualifier ("justly") leaves much more room for interpretation, and possibly suggests a less all-encompassing policy. I consider this question a third category, and the remaining 19481950 questions without the qualifier as the fourth category.

Because of these differences in question wording, caution is needed in analyzing trends over time. Although the first (1937) and fourth (1948-1950) groups of questions share some similarities (they both ask whether the federal government should have authority over state lynching cases, without making reference to specific penalties), the 1937 questions do not refer directly to state action. And while the 1947 question is similar to the 1948-1950 questions in many ways, the ending to the question is much more ambiguous, perhaps suggesting a weaker policy (in turn opening up the possibility of more expressed support). This sort of limitation, however, is an inherent part of the data, and it reflects the difficulties of working with surveys from this era. To better highlight variation in wording, I used different markers in the figures for different categories of questions.

Figure 1 plots trends in support. For the first three data points in 1937, national white support for federal intervention ranges from 59 to 62 percent (the numbers are 59 to 67 percent in the North, compared with 38 to 53 percent in the South). For the next three, when phrasing about punishing local officials is introduced from November 1937 to January 1940, support ranges from 42 to 60 percent (46 to 60 percent in the North, compared with 29 to 58 percent in the South), with the highest figure coinciding with the most minimalist version of this style of question. Postwar, from February 1948 until January 1950 national white support for federal intervention ranges from 38 to 43 percent ( 42 to 47 percent in the North, compared with 23 to 27 percent in the South).$^{81}$

Precise causal inference is impossible to draw from such data, but a few general statements seem consistent with the results. The polling evidence certainly provides no support for the idea that the war led to an increase in support for federal intervention in state lynching cases. It is possible that there was simply no effect of the war (the apparent trend could be random fluctuations, question wording effects, etc.). If anything, there seems to have been an increase in racially conservative opposition. Figure 2 plots the percentage of whites that opposed federal intervention from 1937 until 1950.

81. In 1947, 67 percent offered support when the question used the concluding qualifier.
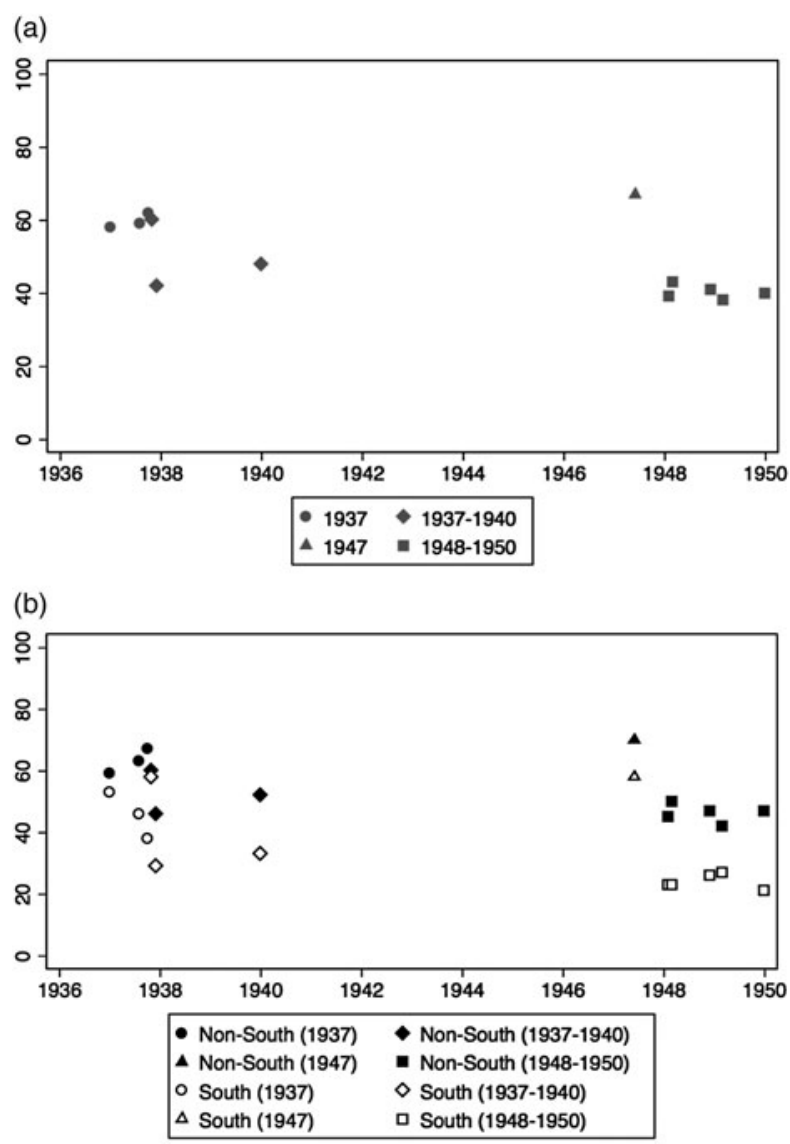

Fig. 1. Percent Supporting Federal Anti-Lynching Legislation.

Before the war, opposition never rose above 43 percent overall, 40 percent in the North, and 56 percent in the South, while "don't know" responses were sometimes as high as 17 to 20 percent. $^{82}$ By January 1950, however, opposition to federal intervention was up to 52 percent overall-a majority-and at a new height of 71 percent in the South. This seems to have been primarily the result of white indecision evolving into a hardened states' rights position, although there appears to have been a slight decline in active support for federal intervention as well.

Comparing Southerners in the most rural areas to northeastern residents in the most urban ones is again revealing, but in a slightly different manner than it was for measures of racial prejudice. In January 1940, 82 percent of whites in the most populous urban areas in the Northeast expressed support for a congressional anti-lynching bill. Between February 1948 and January 1950, support for federal intervention in state lynching cases ranged from 47 to 59

82. And these prewar heights of opposition coincide with the more extreme question wording, which was dropped in the postwar period. 
(a)

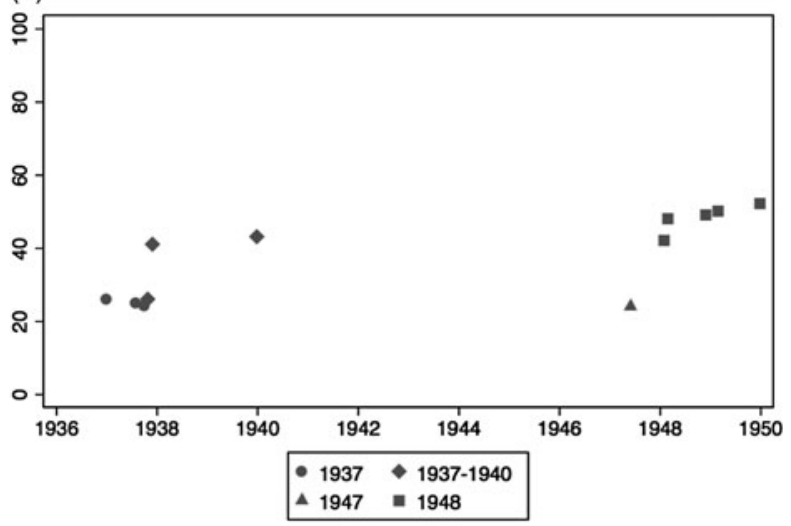

(b)

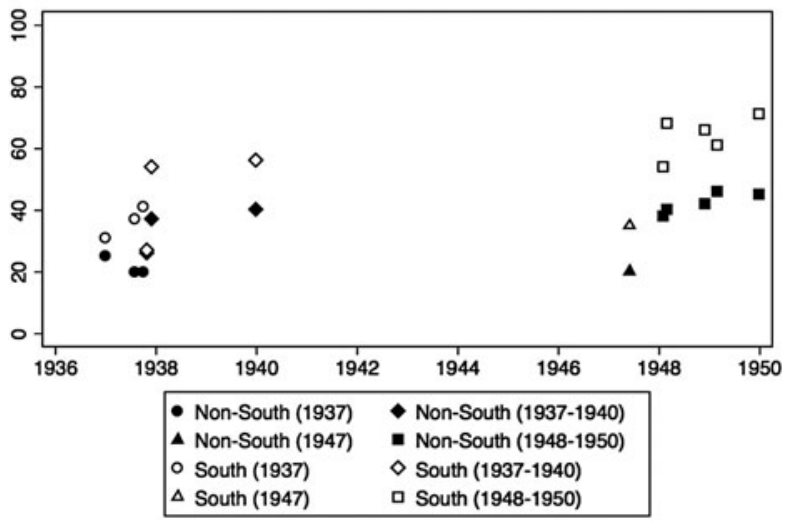

Fig. 2. Percent Opposing Federal Anti-Lynching Legislation.

percent across five different surveys. For whites in the most rural Southern areas, support stood at 27 percent in January 1940, then ranged from 14 to 21 percent in the five surveys conducted between February 1948 and January 1950. The decline in support, then, actually seems, if anything, especially concentrated in the urban Northeast, where support dropped from nearly universal to slightly majoritarian (and, in one case, just a plurality). However, there was less room for a decrease in Southern opinion, since it was already much more opposed. This does not mean the urban Northeast was not more supportive of civil rights liberalism - it was. However, it does highlight the extent to which liberalism was "limited" at this time by mass preferences. Rather than being a window where policy attitudes could become more accommodating, the war seems to have solidified the prospect of such measures and increased skepticism. Anti-lynching legislation was never enacted and eventually fell off the agenda.

So, what might be behind the apparent shift in attitudes? Several factors besides the war cannot be ruled out as possibilities. The number of lynchings had declined since the mid-1930s, which might have led more white respondents to think lynching would go away on its own without federal action. ${ }^{83}$ Another possibility is that it might reflect the NAACP's changing policy focus. By the late 1940s, the organization's civil rights agenda included a wide range of issues beyond lynching, which might have decreased the issue's salience. ${ }^{84}$ An alternate interpretation of this shift in the NAACP's agenda might be that the lynching question came to represent something bigger than lynching per se. Respondents could have perceived that the growth of black militancy during the war was increasing the prospect of other policy changes, with anti-lynching legislation serving as a precedent. It is also possible that a genuine, if unmeasurable, wartime liberalization might have been reversed by developments in the latter half of the 1940s such as the Truman civil rights committee (established in December 1946 and report released in October 1947) or the Dixiecrat movement in $1948 .{ }^{85}$ Whatever the interpretation, the trends presented here can still serve as an important reference point for accounts of the war and racial attitudes. At the very least, while acknowledging a potentially more complicated story, the racial liberalization argument does not seem consistent with the lynching data.

\section{Policy II: Abolition of the Poll Tax, 1940-1949}

The second policy issue that was especially salient prewar was the poll tax. To assess shifts in white attitudes on the poll tax, I used Gallup questions about whether the tax should be abolished. This question was asked once in 1940, then four more times in the late 1940s. Like the lynching questions, however, it was never asked during the war itself. The question wording, fortunately, was very similar over time. "Some Southern states require every voter to pay a poll tax amounting to about a dollar a year before they can vote," the question began. The respondent is then asked whether they think "these poll taxes" should be "abolished" or "done away with" (the specific phrase at the end is the only part that varies over time). The prewar survey allowed respondents to distinguish between "YES!" and "Yes" (also "NO!" and

83. Robert L. Zangrando, The NAACP Crusade Against Lynching, 1909-1950 (Philadelphia: Temple University Press, 1980), 6-7.

84. Ibid., 167.

85. There do not seem to be any notable shifts related to the 1948 presidential campaign. If there was a decrease in support for federal anti-lynching legislation, it likely began earlier than this. However, the potentially confounding influence of the Truman civil rights committee is more difficult to assess. All of the postwar lynching questions discussed here were fielded after the committee's report was released. The only postwar lynching question fielded before the report-albeit well after the committee's establishment-was the June 1947 question that used the "justly" modifier in its phrasing. While expressed support for antilynching legislation was indeed higher here, it is not possible to assess whether this is related to the Truman committee, or merely the qualifier in the question wording resulting in higher levels of support. 
"No"), which is how they articulated preference intensity. However, the postwar surveys simply offered "Yes" and "No" responses, so I collapsed the 1940 survey into simple "YES!" /Yes" and "NO!" / No" categories to allow for comparison. All surveys also allowed the respondents to declare "no opinion," which I again chose to keep in my analysis. The 1940 survey weights were constructed by Berinsky and Schickler, and I used their code to reproduce it (again altering their decision to drop respondents who offered no opinion on the poll tax question). For the postwar questions, I constructed my own weights that correspond to Berinsky and Schickler's preferred education weights ("eduWhites") based on their method.

Figure 3 plots white support for abolishing the poll tax. In December 1940-a year before the United States entered the Second World War-national white attitudes stood at 61 percent wanting to overturn poll taxes, 27 percent wanting to keep them, and 12 percent not offering an opinion. In the South, 51 percent of whites supported getting rid of poll taxes, 40 percent wanted to keep them, and 9 percent did not express an opinion. Jumping forward to the postwar questions, national white support ranged from 63 to 66 percent, and among white Southerners, it ranged from 48 to 53 percent. The evidence, then, points to an increase in support of 2 to 5 percentage points in aggregate white opinion. This is a slight shift, although it is difficult to discern the extent to which it represents a small but real change rather than a slight fluctuation within the margin of sampling error.

There are again some concerns regarding interpretation that merit consideration. The poll tax was a complicated issue in the context of 1940s racial politics. Poll tax opponents in the 1940s tried to frame the issue as a suffrage restriction that hurt poor whites. By focusing on the single issue of the poll tax, they hoped to separate the issue from the broader struggle for black voting rights. Roosevelt himself viewed reforming "Polltaxia" as part of his broader effort in the late 1930s to purge Southern conservatives in his party, which was motivated by a range of issues beyond race. After the United States entered World War II, some advocates used the ideological logic of the war to compare the poll tax's disenfranchisement with elections in fascist Europe. Insomuch as the poll tax was framed by political elites like Roosevelt and national advocacy organizations as a burden on poor whites, using it as a test of racial policy is a bit difficult. That said, it is certainly true that supporters of the poll tax in the South saw it as an important tool in maintaining white supremacy. Some non-Southern liberal Democrats likewise described it in similar terms. Congressman Arthur Mitchell, for example, said abolishing the poll tax would "eventually aid in wiping out the disenfranchisement of Negroes ... in the Southern states"
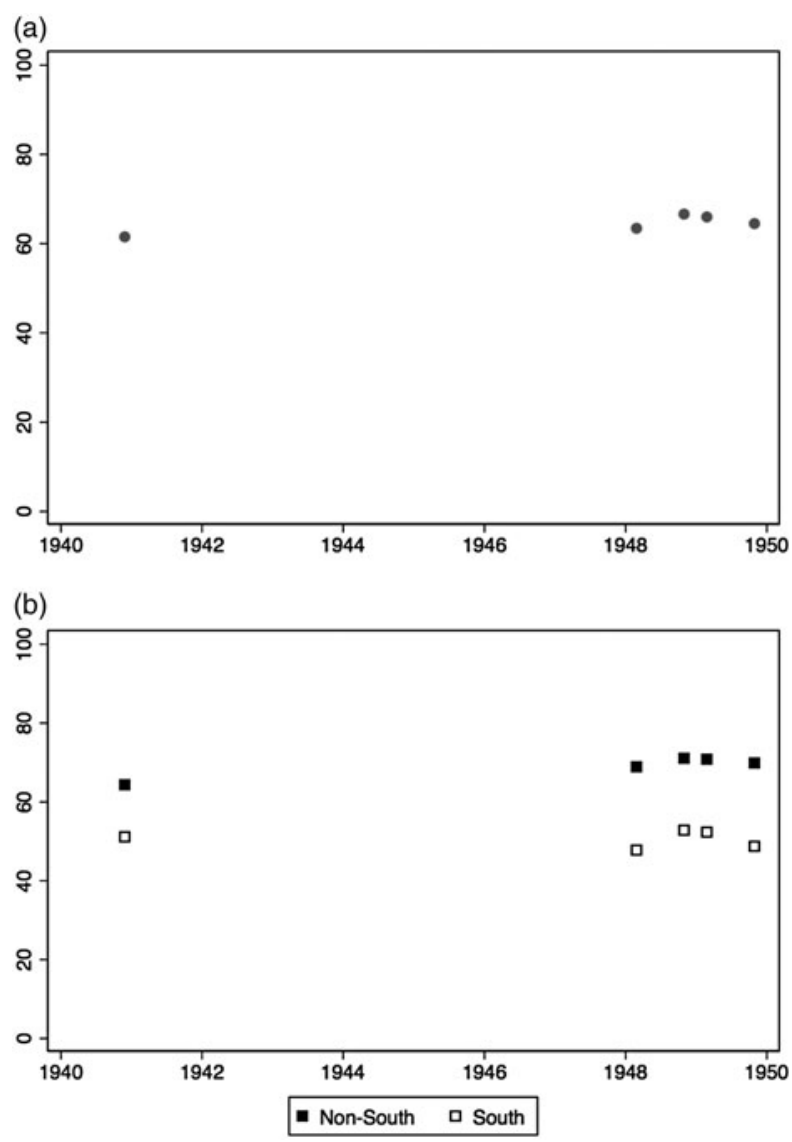

Fig. 3. Percent Supporting Abolition of the Poll Tax.

(for him, a welcome development). ${ }^{86}$ Overall, it would be ill-advised to look only at the poll tax as a measure of racial policy liberalism. However, in conjunction with an analysis of anti-lynching legislation, which was always more explicitly racialized, looking at the relatively small shifts in attitudes toward the poll tax helps fill in the broader picture. The absence of major attitudinal change on the poll tax is not consistent with the racial liberalization argument, at least in its stronger forms.

\section{Summary: Racial Liberalization Hypothesis}

This section demonstrates that, for the most part, white attitudes were not broadly liberalized on race and civil rights as a result of World War II. There is some evidence of a decrease in certain (although not all) measures of white racial prejudice. However, this is counterbalanced by evidence that, if anything, white opposition to federal anti-lynching legislation actually increased. Although the shifts in prejudice should not be totally discounted, the lynching numbers highlight an interesting distinction

86. Steven F. Lawson, Black Ballots: Voting Rights in the South, 1944-1969 (New York: Columbia University Press, 1976), 55-85. 
between measures of prejudice and measures of policy preferences. As such, this section raises doubts about scholarship that has simply assumed, without analyzing the relevant data, that the war had a liberalizing impact on white racial attitudes. This perspective-especially in its more declarative forms-is not supported by the available survey evidence.

It is possible, of course, that some attitudinal changes were not immediate. For example, there might have been a "World War II generation" that experienced the war during their "impressionable years" who came to hold different views on race later in life. This is difficult to identify in the data sets analyzed here, although the veterans section that follows provides one relevant vantage point on individuals whose impressionable years were defined by direct participation in the war. It is also possible that the meaning of "racial liberalism" itself shifted over time, and as such, the proper test of racial liberalization might similarly have shifted. For instance, this article treats attitudes toward federal intervention in state lynching cases as a key measure of racial liberalism. Yet the number of lynchings had fallen significantly by the late 1930 s, and the agenda of the NAACP was moving in a different direction. ${ }^{87}$ It is worth considering what trends over time might look like had questions been asked before and after the war about issues like employment discrimination and housing policy, which were less sectional in nature. ${ }^{88}$ Several other issues also cannot be fully resolved, including sheer data limitations and possible variation in survey response during the decade. While acknowledging such limitations, I argue that the best account of the war's impact on white racial attitudes must be consistent with the evidence that does exist. $^{89}$

\section{RESULTS: RACIAL LIBERALIZATION HYPOTHESIS FOR VETERANS}

This section assesses the second hypothesis, that white veterans of World War II were more racially liberal in the war's aftermath than their nonveteran counterparts. Using two data sets from the earlier analysis of aggregate white racial prejudice, as well as a new data set asking about military integration, I demonstrate that white veterans were not less racially prejudiced in the war's immediate aftermath. They were not distinguishable on general prejudice measures,

87. Zangrando, The NAACP Crusade Against Lynching.

88. It is worth noting that white support for the FEPC was even weaker than support for anti-lynching legislation in the postwar period, so even if such measures did exist, it would be surprising had the war coincided with an increase in white support for the FEPC.

89. These limitations are addressed further in the online appendix. and they were likewise not more willing to support an integrated military. They were, however, more likely to support federal anti-lynching legislation. Shifting focus to 1961-and bringing in the white Southern sample of the Negro Political Participation Study-I demonstrate that white veterans in the South were not distinguishable on attitudes toward segregation and the sit-in movement. However, they were more supportive of black voting rights than nonveterans.

\section{Postwar: Late 1940s}

The 1946 "Minorities; United Nations" NORC survey used earlier contains a wide range of questions about racial prejudice. Fortunately, it also identifies veteran status. For dependent variables, I used five of the racial prejudice questions from the last section (whether African Americans are being treated fairly, whether they should have the same chance at a job, whether black blood is biologically the same as white blood, whether black people are as innately intelligent as white people, and whether the respondent would tolerate having a black nurse). Each variable was dichotomized so that discriminatory positions are coded as 1 and more egalitarian positions are coded as 0 .

Results of a series of logistic regression models are presented in Table 1. Overall, the results are not consistent with the racial liberalization hypothesis for veterans. Controlling for region, education, and age, World War II veterans were perhaps less likely to say white people should get the first chance at a job, but the marginal effect of 9 percentage points is only significant at the .10 level. This might be reasonable since $N=477$, but if the conventional .05 significance level is maintained, the effect does not meet the criteria for statistical significance. Otherwise, there is no distinction between veterans and nonveterans on an array of issues.

I also examined attitudes toward an integrated military. In 1948, Gallup used a split form to ask slight variations on a question about military integration. Those receiving Form $\mathrm{K}$ of the survey were asked, "Would you favor or oppose having Negro and white troops throughout the U.S. Armed Services live and work together-or should they be separated as they are now?" Those receiving Form $\mathrm{T}$ were asked, "It has been suggested that white and colored men serve together throughout the U.S. Armed Services-that is, live and work in the same units. Do you think this is a good idea or a poor idea?" These variables were dichotomized so that opposition is coded as 1 and support for integration is coded as 0 .

I again used logistic regression to estimate the relationship between opinion on military integration and World War II veteran status, controlling for region, education, and age. Results are presented in Table 2. There is no statistical relationship between being a 
Table 1. Anti-Black Prejudice, 1946

\begin{tabular}{|c|c|c|c|c|c|c|}
\hline & Treated Fairly & Job & Blood Diff & Blood DK & Intelligent & Black Nurse \\
\hline \multirow[t]{2}{*}{ Veteran } & -0.25 & -0.36 & 0.15 & -0.24 & 0.08 & 0.06 \\
\hline & $(0.26)$ & $(0.22)$ & $(0.25)$ & $(0.26)$ & $(0.23)$ & $(0.22)$ \\
\hline \multirow[t]{2}{*}{ Northeast } & $-0.79^{* *}$ & $-0.48^{*}$ & -0.16 & -0.13 & -0.21 & $-0.93^{* * *}$ \\
\hline & $(0.29)$ & $(0.24)$ & $(0.28)$ & $(0.29)$ & $(0.25)$ & $(0.24)$ \\
\hline \multirow[t]{2}{*}{ South } & 0.19 & $1.06^{* * *}$ & $0.64^{*}$ & -0.04 & $1.61^{* * *}$ & $0.59^{*}$ \\
\hline & $(0.35)$ & $(0.27)$ & $(0.29)$ & $(0.31)$ & $(0.28)$ & $(0.27)$ \\
\hline \multirow[t]{2}{*}{ West } & $-0.84^{*}$ & -0.31 & -0.14 & 0.67 & 0.04 & -0.42 \\
\hline & $(0.37)$ & $(0.32)$ & $(0.40)$ & $(0.34)$ & $(0.32)$ & $(0.31)$ \\
\hline \multirow[t]{2}{*}{ Grammar School } & $1.13^{* *}$ & 0.35 & $1.11^{* * *}$ & 0.25 & $-0.60^{*}$ & 0.22 \\
\hline & $(0.39)$ & $(0.24)$ & $(0.28)$ & $(0.26)$ & $(0.26)$ & $(0.25)$ \\
\hline \multirow[t]{2}{*}{ College } & $-1.01^{* * *}$ & $-0.93^{* * *}$ & -0.24 & -0.60 & 0.33 & $-0.60^{*}$ \\
\hline & $(0.26)$ & $(0.27)$ & $(0.29)$ & $(0.34)$ & $(0.26)$ & $(0.25)$ \\
\hline \multirow[t]{2}{*}{ Age } & -0.01 & -0.00 & 0.01 & $0.06^{* *}$ & $0.04^{*}$ & 0.00 \\
\hline & $(0.02)$ & $(0.02)$ & $(0.02)$ & $(0.02)$ & $(0.02)$ & $(0.02)$ \\
\hline \multirow[t]{2}{*}{ Constant } & $1.88^{*}$ & 0.18 & -1.33 & $-3.23^{* * *}$ & $-1.98^{* *}$ & 0.38 \\
\hline & $(0.77)$ & $(0.64)$ & $(0.70)$ & $(0.78)$ & $(0.67)$ & $(0.64)$ \\
\hline Pseudo $R^{2}$ & .10 & .09 & .06 & .06 & .10 & .07 \\
\hline Log Likelihood & -223.35 & -299.78 & -234.22 & -245.35 & -287.84 & -304.90 \\
\hline $\mathrm{N}$ & 428 & 477 & 381 & 490 & 468 & 474 \\
\hline
\end{tabular}

Notes: Standard errors in parentheses. ${ }^{* * *} p<0.001,{ }^{* *} p<0.01,{ }^{*} p<0.05$.

Table 2. Integrating the Military, 1948

\begin{tabular}{lcc}
\hline & Live and Work & Serve \\
\hline Veteran & 0.33 & 0.30 \\
Northeast & $(0.30)$ & $(0.27)$ \\
& $-0.91^{* *}$ & -0.40 \\
South & $(0.29)$ & $(0.28)$ \\
& $1.80^{*}$ & $2.63^{* * *}$ \\
West & $(0.76)$ & $(0.76)$ \\
& -0.08 & 0.18 \\
Grammar School & $(0.37)$ & $(0.36)$ \\
& -0.01 & 0.36 \\
HS Grad & $(0.44)$ & $(0.39)$ \\
& -0.46 & 0.33 \\
College & $(0.38)$ & $(0.37)$ \\
& -0.67 & -0.58 \\
Age & $(0.38)$ & $(0.35)$ \\
Constant & 0.02 & 0.04 \\
Pseudo $R^{2}$ & $(0.02)$ & $(0.02)$ \\
Log Likelihood & 0.51 & -0.74 \\
N & $(0.92)$ & $(0.80)$ \\
\hline
\end{tabular}

Notes: Standard errors in parentheses. ${ }^{* * *} p<0.001,{ }^{* *} p<0.01$, ${ }^{*} p<0.05$. veteran and attitudes toward military integration. This result is consistent for both versions of the question. Given the salience of the military integration policy debate in the postwar period-and the ideological tension between a war for democracy waged by a segregated military - this null result is quite striking.

Finally, some of the postwar lynching questions were part of surveys that asked whether respondents served in World War II. Here, I examine a 1948 question asking respondents, "At present, state governments deal with most crimes committed in their own states. In the case of a lynching, do you think the United States (Federal) Government should have the right to step in and deal with the crimeor do you think this should be left entirely to the state government?" The variable was dichotomized so that leaving lynching cases to the states is coded as 1 and allowing the federal government to intervene is coded as 0 .

I again used logistic regression to estimate the relationship between opinion on federal intervention in state lynching cases and World War II veteran status, controlling for region, education, and age. Results are presented in Table 3. These results provide the strongest positive evidence supporting the hypothesis that white veterans were liberalized on race. The "National" model column shows that veteran status has a statistically significant relationship with attitudes toward anti-lynching legislation. Calculating marginal 
Table 3. Lynching, 1948

\begin{tabular}{lccc}
\hline & National & North & South \\
\hline Veteran & $-0.38^{*}$ & $-0.41^{*}$ & 0.02 \\
& $(0.18)$ & $(0.19)$ & $(0.56)$ \\
Northeast & $-0.67^{* *}$ & & \\
South & $(0.19)$ & & \\
& 0.42 & & \\
West & $(0.27)$ & & \\
& -0.42 & & \\
Grammar School & $(0.25)$ & & \\
& -0.32 & -0.25 & -0.51 \\
HS Grad & $(0.26)$ & $(0.28)$ & $(0.67)$ \\
& 0.16 & 0.08 & 0.81 \\
College & $(0.24)$ & $(0.25)$ & $(0.70)$ \\
& -0.31 & -0.38 & 0.11 \\
Age & $(0.23)$ & $(0.24)$ & $(0.66)$ \\
& 0.02 & 0.01 & 0.03 \\
Constant & $(0.01)$ & $(0.01)$ & $(0.04)$ \\
Pseudo $R^{2}$ & -0.28 & -0.46 & -0.59 \\
Log Likelihood & $(0.50)$ & $(0.52)$ & $(1.62)$ \\
N & .04 & .02 & .04 \\
& -444.27 & -394.54 & -54.60 \\
\hline
\end{tabular}

Notes: Standard errors in parentheses. ${ }^{* *} p<0.001,{ }^{*} p<0.05$.

effects, white veterans were 9 percentage points less likely to take the states' rights position, relative to the federal intervention choice. The "North" and "South" models show this to be an entirely nonSouthern effect. If the model is estimated using only Southern respondents, the veteran variable is not significant. However, if it is estimated using only nonSouthern respondents, the effect of military service is slightly larger than in the full model (10 percentage points in this case).

\section{The Civil Rights Era: Early 1960s}

While the immediate impact of military service on racial attitudes is interesting, the longer-term impact of military service on later racial attitudes also merits examination, especially in the era when civil rights politics were most primed. This analysis also allows me to relate this project more directly to Parker's work on the attitudinal and behavioral impact of black veterans' military service. Relying on the white sample of the 1961 Negro Political Participation Study, I used the following questions as dependent variables: the respondent's assessment of how many white people in the South favor racial segregation; whether the respondent themselves favors "integration, strict segregation, or something in between"; their agreement with the statement, "colored people ought to be allowed to vote"; assessment of the sit-in movement ("that is, some of the young colored people going into stores, and sitting down at lunch counters, and refusing to leave until they are served"); their agreement with the statement, "Demonstrations to protest integration of schools are a good idea, even if a few people have to get hurt"; whether they have ever "ever known a colored person well enough that you would talk to him as a friend"; and whether they agree that "colored people are all alike."

I estimated regression models where opinion is a function of veteran status, as well as age and educational attainment. The sample is restricted to Southern whites by default. As previously noted, I also restricted it to those men between the ages of 38 and 65. For dependent variables with multiple, ordered response categories, I estimated ordered probit models. Variables were coded so that higher values are more racially conservative. For the dichotomous question about friendship-as well as an alternate coding of the sit-ins variable-I used logistic regression. To aid in interpretation, I calculated changes in probabilities for theoretically relevant shifts, as well as the average change, for the veteran variable in the ordered probit models. I also calculated the marginal effect of moving from 0 to 1 on the veteran variable (i.e., moving from not being a veteran to being a veteran) for the logistic regression models.

Results are presented in Tables 4 and 5. The strongest support for the racial liberalization hypothesis for veterans is found in the model assessing attitudes on black voting rights. The coefficient on the veteran

Table 4. Negro Political Participation Study White Sample, Logit Models, 1961

\begin{tabular}{lcc}
\hline & Sit-ins & Friend \\
\hline Veteran & -0.39 & $0.89^{*}$ \\
& $(0.50)$ & $(0.42)$ \\
Age & -0.03 & 0.02 \\
& $(0.03)$ & $(0.02)$ \\
Grammar School & 0.23 & -0.12 \\
& $(0.75)$ & $(0.56)$ \\
HS Grad & -0.03 & 0.21 \\
& $(0.77)$ & $(0.60)$ \\
College & -1.04 & 0.78 \\
& $(0.77)$ & $(0.71)$ \\
Constant & $3.33^{*}$ & -0.78 \\
& $(1.66)$ & $(1.37)$ \\
Pseudo $R^{2}$ & .05 & .05 \\
Log Likelihood & -64.59 & -89.55 \\
N & 137 & 144 \\
\hline
\end{tabular}

Notes: Southern sample. Standard errors in parentheses. ${ }^{*} p<0.05$. 
Table 5. Negro Political Participation Study White Sample, Ordered Probit Models, 1961

\begin{tabular}{|c|c|c|c|c|c|c|}
\hline & Segregation 1 & Segregation 2 & Black Voting & Sit-ins & Anti-Integration & All Alike \\
\hline Veteran & $\begin{array}{c}0.06 \\
(0.22)\end{array}$ & $\begin{array}{c}-0.13 \\
(0.23)\end{array}$ & $\begin{array}{c}-0.69^{* *} \\
(0.26)\end{array}$ & $\begin{array}{c}-0.18 \\
(0.21)\end{array}$ & $\begin{array}{c}0.28 \\
(0.26)\end{array}$ & $\begin{array}{c}0.19 \\
(0.25)\end{array}$ \\
\hline Age & $\begin{array}{c}-0.00 \\
(0.01)\end{array}$ & $\begin{array}{c}-0.00 \\
(0.01)\end{array}$ & $\begin{array}{c}-0.00 \\
(0.01)\end{array}$ & $\begin{array}{c}-0.01 \\
(0.01)\end{array}$ & $\begin{array}{c}0.00 \\
(0.02)\end{array}$ & $\begin{array}{r}-0.01 \\
(0.01)\end{array}$ \\
\hline Grammar School & $\begin{array}{c}-0.03 \\
(0.31)\end{array}$ & $\begin{array}{c}0.50 \\
(0.34)\end{array}$ & $\begin{array}{c}0.24 \\
(0.36)\end{array}$ & $\begin{array}{c}0.12 \\
(0.31)\end{array}$ & $\begin{array}{c}-0.39 \\
(0.36)\end{array}$ & $\begin{array}{r}-0.11 \\
(0.35)\end{array}$ \\
\hline HS Grad & $\begin{array}{c}-0.33 \\
(0.33)\end{array}$ & $\begin{array}{c}0.07 \\
(0.34)\end{array}$ & $\begin{array}{c}0.04 \\
(0.37)\end{array}$ & $\begin{array}{c}0.03 \\
(0.32)\end{array}$ & $\begin{array}{c}0.08 \\
(0.38)\end{array}$ & $\begin{array}{r}-0.08 \\
(0.36)\end{array}$ \\
\hline College & $\begin{array}{r}-0.82^{*} \\
(0.36)\end{array}$ & $\begin{array}{c}-0.61 \\
(0.37)\end{array}$ & $\begin{array}{c}-0.65 \\
(0.48)\end{array}$ & $\begin{array}{c}-0.38 \\
(0.35)\end{array}$ & $\begin{array}{c}1.03 \\
(0.55)\end{array}$ & $\begin{array}{r}1.07^{*} \\
(0.52)\end{array}$ \\
\hline Cut 1 & $\begin{array}{c}-2.08^{* *} \\
(0.77)\end{array}$ & $\begin{array}{r}-1.63^{*} \\
(0.78)\end{array}$ & $\begin{array}{c}0.32 \\
(0.81)\end{array}$ & $\begin{array}{c}-2.70^{* * *} \\
(0.76)\end{array}$ & $\begin{array}{c}-1.12 \\
(0.86)\end{array}$ & $\begin{array}{r}-1.49 \\
(0.84)\end{array}$ \\
\hline Cut 2 & $\begin{array}{r}-1.49^{*} \\
(0.76)\end{array}$ & $\begin{array}{c}-0.51 \\
(0.77)\end{array}$ & $\begin{array}{c}1.04 \\
(0.81)\end{array}$ & $\begin{array}{c}-2.00^{* *} \\
(0.73)\end{array}$ & $\begin{array}{c}-0.78 \\
(0.86)\end{array}$ & $\begin{array}{r}-1.27 \\
(0.84)\end{array}$ \\
\hline Cut 3 & $\begin{array}{c}0.01 \\
(0.75)\end{array}$ & & $\begin{array}{c}1.22 \\
(0.81)\end{array}$ & $\begin{array}{r}-1.48^{*} \\
(0.72)\end{array}$ & $\begin{array}{c}-0.42 \\
(0.86)\end{array}$ & $\begin{array}{r}-0.82 \\
(0.84)\end{array}$ \\
\hline Cut 4 & & & & $\begin{array}{c}0.09 \\
(0.71)\end{array}$ & & \\
\hline Pseudo $R^{2}$ & .03 & .07 & .07 & .02 & .07 & .05 \\
\hline Log Likelihood & -147.05 & -112.07 & -112.94 & -158.84 & -117.77 & -123.52 \\
\hline $\mathrm{N}$ & 137 & 141 & 142 & 137 & 138 & 143 \\
\hline
\end{tabular}

Notes: Southern sample. Standard errors in parentheses. ${ }^{* *} p<0.001,{ }^{* *} p<0.01,{ }^{*} p<0.05$.

variable is statistically significant. When the changes in probabilities are calculated, the evidence largely points to differences in preference intensity, rather than sheer differences of opinion. Southern whites with military backgrounds were 21 percentage points more likely than those without military backgrounds to offer strong support, relative to the weaker support option. However, the other categorical shifts are much smaller. The overall average change associated with military service is 11 percentage points. For this issue, at least, there is support for the racial liberalization hypothesis for veterans. ${ }^{90}$ White veterans were also 19 percentage points more likely than nonveterans to say they had a black friend. Although the "black friend" trope is a cliché one, it lends some support to the idea that white veterans' relative moderation, at least on some issues, was partly fueled by contact.

90. Looking at bivariate cross-tabulations is informative here because they are nearly unanimous. Among the 58 male veterans in the 38-65 age group, 49 "agree[d] quite a bit" that African Americans should be able to vote (84 percent). Another 6 "agree [d] a little." One respondent in this group "disagree[d] a little and one other respondent "disagree[d] quite a bit." A final respondent offered a "don't know" response. Among men in this age group who were not veterans, 60 percent "agree[d] quite a bit," 22 percent "agree[d] a little," and 13 percent of these nonveterans "disagree[d] quite a bit."
However, there is no difference whatsoever between veterans and nonveterans on assessments of the sit-in protests or general attitudes toward segregation. This is a clear rebuke of the racial liberalization hypothesis. Segregation was at the core of the Southern racial status quo, and military service seems to have had no moderating effect on how Southern white men felt about the issue. Similarly, the sit-in movement was a critical aspect of the 1960s civil rights movement, and military service likewise seems to have had no impact on white assessments of it. ${ }^{91}$

\section{Summary: Racial Liberalization Hypothesis for Veterans}

This section provides evidence that white veterans' military service corresponded with more moderate racial attitudes on some issues, but not others.

91. It is possible there is variation between the Peripheral/Rim and Deep South states. The Peripheral South can be defined as Arkansas, Florida, North Carolina, Tennessee, Texas, and Virginia, and the Deep South can be defined as Alabama, Georgia, Louisiana, Mississippi, and South Carolina. This definition is used by many standard texts in southern politics, including Key, Southern Politics in State and Nation. Unfortunately, it is difficult to definitely assess such a distinction, because the number of observations in the Deep South is quite small by the conventions of survey research. The $N$ of 142 for the black voting model, for example, can be broken down into 107 Peripheral South respondents and 35 Deep South respondents. 
White veterans overall were less likely to oppose federal intervention in state lynching cases in 1948, although this seems to have been concentrated among non-Southerners. White veterans in the South offered stronger support for black voting rights in 1961. However, they did not evince less racial prejudice than nonveterans in the war's immediate aftermath, and by 1961 Southern white veterans were not distinguishable from white Southerners as a whole on questions of segregation. On the one hand, then, veterans seem to have liberalized on at least some of these more difficult questions of policy, whereas this was not the case for the white mass public as a whole. On the other hand, this moderation did not extend to broader claims about racial integration. The white veterans analyzed in the 1960 s were just as supportive of Jim Crow segregation as Southern whites who did not serve, and they were not any more sympathetic to the sit-in movement.

Mechanisms are difficult to tease out. The exposure to more egalitarian cultures argument is a theoretically appealing one, but it is difficult to empirically test given the available data. ${ }^{92}$ Another possibility is the contact hypothesis, as white veterans in the South in 1961 were much more likely to report they had a black friend than nonveterans. ${ }^{93}$ Of course, the war's effects on contact between black men and white men were complex. On the home front, black soldiers stationed in Southern training centers came into contact with both white soldiers and nonmilitary whites. Black men and white men also were more likely to work together in the defense industry than they had been before the war. This increased contact certainly did not lead easily to toleration and integration, as race riots and other incidents of racial violence on the home front make clear. ${ }^{94}$

92. Surveys that identify veteran status and provide a nonveteran comparison group do not usually go beyond a veteran/nonveteran distinction. In particular, they do not identify where the individual served.

93. The interpretation here is not so straightforward, however. If the friend variable is used as a predictor for racial attitudes instead of the veteran variable, it is also statistically significant. If the veteran variable is used but the sample is restricted to only those with black friends, veteran status is no longer significant. However, if veteran is used, but the sample is restricted to only those without black friends, veteran status is significant, suggesting that the war had some other effect than mere contact. These initial results are available in the online appendix, but more research is merited in untangling the contact hypothesis's role here. For a recent analysis that tries to assess the causal effect of the contact hypothesis in a (contemporary) military setting, see Scott E. Carrell, Mark Hoekstra, and James E. West, "The Impact of Intergroup Contact on Racial Attitudes and Revealed Preferences" (NBER Working Paper 20940, National Bureau of Economic Research, Cambridge, MA, 2015).

94. Kryder, Divided Arsenal. Historians of housing politics have likewise demonstrated intense anti-black sentiments among white urban residents who came into contact with growing black populations. See, for example, Arnold Hirsch, Making the Second Ghetto: Race and Housing in Chicago, 1940-1960 (Chicago: University of Chicago Press, 1998).
While the exact mechanism is difficult to fully identify, these results nonetheless contribute to scholarly accounts of the war's effects on American racial politics, and they complement research about the effects of military service on black veterans.

\section{CONCLUSION}

Claims about World War II's impact on white racial attitudes are widespread, yet they are generally made without examining survey data that might better substantiate such claims. This article provides an empirical baseline for future claims to draw from. First, I demonstrated that while there is some evidence of slight shifts in racial prejudice, the war did not generally liberalize white attitudes toward racially egalitarian policies. This is especially true for anti-lynching legislation, where opposition actually seems to have grown. The more specific case of veterans is somewhat more complex. White veterans were not distinguishable on a range of racial attitudes, but they were more likely to support federal anti-lynching legislation in 1948, and those in the South offered stronger support for black voting rights by 1961 .

Scholars should generally take care when making claims about wartime attitudinal change without reference to the survey evidence presented here. Popular interpretations of Myrdal that emphasize the necessity of racial attitude change during the war seem inconsistent with the evidence in this article. The work of Myrdal is better seen as a primary source representing the contemporaneous expectations of a particular strand of white racial liberalism than as an empirical treatment of white attitudes. Similarly, claims based on secondary references to survey results reported in newspaper and historical accounts could be better substantiated with reference to the more extensive and methodologically attentive analysis of the available survey evidence presented in this article.

There are several remaining questions for future research. The potentially heterogeneous effects of the war on mass attitudes merit further examination. For instance, scholars could go deeper than my comparison of whites in the urban Northeast and whites in the rural South by looking at specific groups that might be "most likely" to be affected ${ }^{95}$ Any differences that emerge in such subgroup analysis might also highlight the limits of looking at aggregate shifts. Future research might also consider the extent to which a "World War II generation" came to view

95. Young, non-Protestant whites in the most urban parts of the Northeast working in industries organized by the CIO would likely be prime candidates. Of course, at a certain point the limits of subgroup survey analysis will be reached, but such subgroups might be more theoretically relevant for stories of twentieth-century realignment than the subgroups I analyzed in this article. 
race and civil rights differently in later decades. ${ }^{96} \mathrm{~A}$ third possibility is conducting a similar study using a more expansive definition of "public opinion" than survey responses. Taeku Lee's work demonstrates the usefulness of examining constituent mail as an alternate measure of public opinion less susceptible to top-down issue framing than survey research. ${ }^{97}$ This might be especially useful in examining nonSouthern white racial attitudes, as issues like housing were not examined by pollsters but might well have been discussed by constituents in letters to politicians. Researchers might also try to tease out a clear mechanism underlying the shifts in the attitudes of white veterans described in this article. While certainly not an exhaustive list, these four suggestions highlight a few potential starting points for future research building on this article.

Of course, there is much more to the story of World War II and American racial politics than white public opinion. This article provides one vantage point on the war's effects on American racial politics, and the politics of civil rights in the 1940s more broadly. While I have focused on the ideological aspects of the war, the massive material undertaking of wartime had other important political-economic implications for race and civil rights politics. The creation of jobs in the defense industry helped propel black migration out of the South into urban areas in other parts of the country. Mobilization of these new potential voters led to new forms of political influence in important swing states. ${ }^{98}$ Perhaps the most direct policy impact of the war was President Roosevelt's FEPC executive order, which was issued almost entirely in response to a threatened March on Washington by A. Philip Randolph and others. ${ }^{99}$

96. Schuman et al. emphasize this sort of generational change, but they do not identify a World War II cohort, per se. Rather, they identify a "pre-civil rights cohort," which includes individuals who reached adulthood before 1953. Schuman et al., Racial Attitudes in America, 202. See also Danny Osborne, David O. Sears, and Nicholas A. Valentino, "The End of the Solidly Democratic South: The Impressionable-Years Hypothesis," Political Psychology 31, no. 1 (2011): 9-10.

97. Lee, Mobilizing Public Opinion.

98. This was often articulated as African Americans holding the "balance of power." See Henry Lee Moon, The Balance of Power: The Negro Vote (Garden City, NY: Doubleday, 1948). It also finds expression in the influential Rowe memorandum urging Truman to ignore Southern whites and emphasize the mobilization of black northern voters. "Unless there are new and real efforts (as distinguished from mere political gestures which are today thoroughly understood and strongly resented by sophisticated Negro leaders) the Negro bloc, which, certainly in Illinois and probably in New York and Ohio, hold the balance of power, will go Republican," Rowe wrote Truman. The memorandum is available online at "Oral History Interview with James H. Rowe," September 30, 1969 and January 15, 1970, Appendix B, Oral History Interviews, Harry S. Truman Library \& Museum, http://www.trumanlibrary.org/ oralhist/rowejhap.htm\#appb.

99. Louis Coleridge Kesselman, The Social Politics of FEPC: A Study in Reform Pressure Movements (Chapel Hill: University of North Carolina Press, 1948); Herbert Garfinkel, When Negroes
While the wartime FEPC was often viewed as weak in its enforcement powers, Anthony Chen argues that the effort to save the wartime FEPC "served as a catalyst for grass-roots mobilization" and "spurred a wider range of liberal interest groups to collaborate more closely with each other-in the name of civil rights-than ever before in the twentieth century." The wartime experience with FEPC led to "a specific regulatory ideal and concrete legislative program" for the immediate postwar period. ${ }^{100}$

This was partly enabled by an alliance formed on the eve of the war between the NAACP and the CIO. NAACP membership increased nearly tenfold during the war, and half a million black workers joined CIO-affiliated unions during the era. ${ }^{101}$ This had important implications for civil rights politics. Christopher Baylor contrasts this alliance with the National Urban League, which allied itself with business, particularly in terms of its donor base. Counterfactually, had the NAACP allied with business instead of labor, Baylor argues that the push for FEPC—-which the NAACP came to view as the most important issue on the agenda-would have been even more difficult. ${ }^{102}$ This, in turn, had implications for party politics. When the NAACP and CIO advocated for a permanent FEPC over other goals, including the desegregation of the military, "whatever lingering relationship remained between African Americans and the Republican Party was strained" because the GOP considered the FEPC to be "the most unpalatable civil rights proposal on the NAACP's agenda." ${ }^{103}$ Changes of this sort do not directly involve changes in aggregate white racial attitudes, and as such are a different avenue through which the war might have affected race and civil rights politics.

Other scholars have written about this era as the moment when Northern Democrats starting becoming more racially liberal than Northern Republicans.

March: The March on Washington Movement in the Organizational Politics for FEPC (New York: Atheneum, 1973); Anthony S. Chen, The Fifth Freedom: Jobs, Politics, and Civil Rights in the United States, 1941-1972 (Princeton, NJ: Princeton University Press, 2009).

100. Chen, The Fifth Freedom, 33.

101. Sitkoff, "Racial Militancy and Interracial Violence," 663; Robert Korstad and Nelson Lichtenstein, "Opportunities Found and Lost: Labor, Radicals, and the Early Civil Rights Movement," Journal of American History 75, no. 3 (1988): 787. In the words of Korstad and Lichtenstein in the source just mentioned, "the social structure of black America took on an increasingly urban, proletarian character," in contrast to a previously "predominantly southern rural and small town population" (p. 786).

102. Christopher A. Baylor, "First to the Party: The Group Origins of the Partisan Transformation on Civil Rights," Studies in American Political Development 27, no. 2 (2013): 121. For further discussion of the timing of this shift in the NAACP's stance toward unions, see Beth Tompkins Bates, "A New Crowd Challenges the Agenda of the Old Guard in the NAACP, 1933-1941," American Historical Review 102, no. 2 (1997): 340-77.

103. Baylor, "First to the Party," 129. 
Brian Feinstein and Eric Schickler, for example, offer a compelling critique of the Carmines and Stimson model of the civil rights realignment by pushing the timing of this partisan shift back to the mid-1940s. Non-Southern state Democratic Parties, they argue, were becoming more racially liberal than their Republican counterparts by this time period. They focus on two domestic mechanisms through which the Democratic Party gradually adopted more racially liberal policies than Republicans: (1) Critical constituents in the Democratic coalition, like Jews and CIO members, were more predisposed toward civil rights liberalism than the business-oriented constituents of the Republican Party, and (2) the "ideological logic of the New Deal itself," by which they mean the movement of the party toward a rights-based focus combined with a willingness to use the federal government to intervene in society, made racial liberalism an easier fit with the Democratic Party's postwar policy agenda. ${ }^{104}$ If the war did not lead to a liberalization of white attitudes, what accounts for this? One possibility is that the connection between economic liberalism and racial liberalism was being cemented at this time, regardless of the nature of aggregate attitudinal shifts. ${ }^{105}$ It is also possible that the views and incentives of state party activists were influenced by the war, either ideologically (e.g., idiosyncratic responses to the war by important actors, whose decisions had institutional implications) or in more material ways (e.g., electoral pressures caused by black migration). The latter is almost certainly true, while the former would be more difficult to pin down. To what extent were non-Southern state party activists in agreement with Rabbi Aryeh Lev's declaration to the 1948 Democratic National Convention, "We have learned a measure of unity on the battlefield where all under the same banner, white men and black men ... have fought and died side by side. Now that we are at peace, we must learn to live side by side"? ${ }^{106}$ While individual comments like this are interesting, a more systematic analysis of the archival record would be necessary to assess this.

These results can also be connected to the presidential politics of civil rights at the time. The growth in white opposition to federal anti-lynching legislation, particularly insomuch as it came from

104. Brian Feinstein and Eric Schickler, "Platforms and Partners: The Civil Rights Realignment Reconsidered," Studies in American Political Development 22 (2008): 5-6; Carmines and Stimson, Issue Evolution.

105. Schickler, "New Deal Liberalism." See also Eric Schickler and Devin Caughey, "Public Opinion, Organized Labor, and the Limits of New Deal Liberalism," Studies in American Political Development 25 (2011): 162-189. Korstad and Lichtenstein make a similar point, noting that "civil rights advocacy was becoming a defining characteristic of urban liberalism" at this time. Korstad and Lichtenstein, "Opportunities Found and Lost," 800.

106. C. Edgar Brown, ed., Democracy at Work (Philadelphia: Local Democratic Political Committee of Pennsylvania, 1948), 97. indecision shifting into such opposition, might well be a response to fears that the Double- $V$ rhetoric of civil rights organizations was successful. This was something the White House sensed as well. For example, in a November 25, 1942, memorandum to President Roosevelt from Jonathan Daniels about the FEPC investigation of the Capital Transit Company, Daniels wrote that the move was helping to "create Southern fears that the government may be moving to end Jim Crow laws in transportation in the South under the guise of the war effort." 107 Growing white Southern opposition to federal antilynching legislation might be similarly motivated. ${ }^{108}$

The finding that veterans were more likely to oppose the extremes of white supremacist violence and the most blatant form of democratic exclusion (yet offer similar levels of support as nonveterans for a maintenance of the racial status quo in other ways) is in many ways similar to the story of President Truman's evolving civil rights positions. Privately, Truman was born into a very culturally Southern part of Missouri, and he casually used racial slurs throughout his life. However, Truman's service in the First World War was a critical moment in his life, and he developed a particular concern with the treatment of soldiers. When the National Emergency Committee Against Mob Violence presented him with evidence of black veterans returning home only to be beaten by police, often while wearing their uniforms, he was personally affected in a way Roosevelt never would have been. The blinding of Sergeant Isaac Woodard in South Carolina by an officer's billy club was a particularly striking example for Truman. ${ }^{109}$ Such emotional reactions did not lead him to support desegregation and the civil rights movement more broadly. Indeed, later in life he would come to view the 1960s movement as unruly and possibly Communist in nature. ${ }^{110}$ However, it did at least press him at the margins to say soldiers deserved better than mob violence. It is quite possible

107. Jonathan Daniels to Franklin Roosevelt, memorandum, November 25, 1942, "Colored Matters (Negroes)," Box 5, OF 93, Franklin D. Roosevelt President's Official Files, 1933-1945, Franklin D. Roosevelt Library, Hyde Park, NY.

108. In comparison to civil rights advocates' Double-V campaign, Jason Morgan Ward describes how "defenders of segregation articulated their own vision of Double Victory. Championing white supremacy and demanding freedom from outside interference, Southern conservatives deemed civil rights agitation and federal encroachment to be as dangerous as an Axis invasion. The white South, like African Americans, had entered the war fighting on two fronts." He later describes this effort as "more than an elite rhetorical strategy but less than an authentic grassroots rebellion." Jason Morgan Ward, "'A War for States' Rights': The White Supremacist Vision of Double Victory," in Fog of War: The Second World War and the Civil Rights Movement, ed. Kevin M. Kruse and Stephen Tuck (New York: Oxford University Press, 2012), 127, 140. 109. David McCullough, Truman (New York: Simon \& Schuster, 1992); see also Klinkner and Smith, The Unsteady March, 204.

110. McCullough, Truman, 971-72. 
that at least some white veterans of the Second World War had a similar understanding. ${ }^{111}$

The World War II era, of course, eventually shifts into the Cold War era, which has a race and civil rights literature of its own. Mary Dudziak demonstrates how the Cold War would "simultaneously constrain and enhance civil rights reform," as well as "frame and thereby limit the nation's civil rights commitment."112 Carol Anderson acknowledges this "halfhearted, but necessary, response to black inequality," but argues that it also "systematically eliminated human rights as a viable option for mainstream African American leadership." 113 Anti-communism, in particular, was able to make certain civil rights stances more palatable while defanging more radical positions. Accounts of World War II and civil rights differ in the extent to which they interpret the war as a compelling or constraining force for civil rights. Klinkner and Smith, for example, offer a more positive case: The war contained the necessary conditions for progress on civil rights. ${ }^{114}$ Others, like Kryder, emphasize the national state's efforts at maintaining order, which sometimes led to racially egalitarian outcomes (the wartime FEPC) and other times led to racially inegalitarian outcomes (segregation in the military). ${ }^{115}$ Further distinguishing the World War II era from the Cold War era-and more systematically distinguishing the ways in which the war was "good" or "bad" for civil rights-merits further analysis. 116

Understanding the impact of the war on white racial attitudes is a part of this broader story. This article illustrates how the mix of relative continuity (e.g., attitudes toward the poll tax), liberalization (e.g., white veterans' opposition to lynching), and rightward shifts (e.g., aggregate white attitudes toward federal anti-lynching legislation) complicates popular assumptions about the war's impact. In conjunction with a careful analysis of the war's impact on political institutions, this article can help clarify the complex role played by the Second World War in shaping twentieth-century racial politics in the United States. $^{117}$

\section{SUPPLEMENTRY MATERIALS AND METHODS}

The supplementry material referred to in thie article can be found online at http://dx.doi.org/10.1017/ S0898588X16000055.
111. Of course, not all white veterans felt this way. See Brooks, Defining the Peace. Indeed, many ardent white supremacists had served in the war and saw no tension between their service in a war against Nazism and their defense of white supremacy. Robert "Tut" Patterson, leader of the White Citizens' Councils, was a World War II veteran. James C. Cobb, The South and America since World War II (New York: Oxford University Press, 2012), 35.

112. Mary L. Dudziak, Cold War Civil Rights: Race and the Image of American Democracy (Princeton, NJ: Princeton University Press, 2000), 11, 13.

113. Carol Anderson, Eyes Off the Prize: The United Nations and the African American Struggle for Human Rights, 1944-1955 (New York: Cambridge University Press, 2003), 5.

114. Klinkner and Smith, The Unsteady March.
115. Kryder, Divided Arsenal.

116. More broadly, this fits with calls for greater attention, especially among Americanists, to the effects of war on domestic politics. Ira Katznelson and Martin Shefter, eds., Shaped by War and Trade: International Influences on American Political Development (Princeton, NJ: Princeton University Press, 2002); David R. Mayhew, "Wars and American Politics," Perspectives on Politics 3, no. 3 (2005): 473-93; Elizabeth Kier and Ronald R. Krebs, eds., In War's Wake: International Conflict and the Fate of Liberal Democracy (New York: Cambridge University Press, 2010).

117. This argument is articulated in more detail in a larger, book-length project. See also Steven White, "For Democracy and a Caste System? World War II, Race, and Democratic Inclusion in the United States" (PhD diss., Columbia University, 2014). 